\title{
Modulation of Oxidative Stress and Inflammation in the Aged Lacrimal Gland
}

\author{
Rodrigo G. de Souza, ${ }^{\dagger \dagger}$ Zhiyuan Yu, ${ }^{*}$ Humberto Hernandez, ${ }^{*}$ Claudia M. Trujillo-Vargas, ${ }^{*}$ Andrea Lee, ${ }^{\S}$ Kelsey E. Mauk,
} Jiyang Cai, "Milton R. Alves, ${ }^{\dagger}$ and Cintia S. de Paiva ${ }^{* \dagger}$

From the Department of Ophthalmology* and the Graduate Program in Immunology and Microbiology, ${ }^{\S}$ Baylor College of Medicine, Houston, Texas; the Department of Ophthalmology, ${ }^{\dagger}$ University of São Paulo, São Paulo, Brazil; the Grupo de Inmunodeficiencias Primarias, ${ }^{\ddagger}$ Facultad de Medicina, Universidad de Antioquia, Medellin, Colombia; and the Department of Physiology, "University of Oklahoma Health Sciences Center, Oklahoma City, Oklahoma

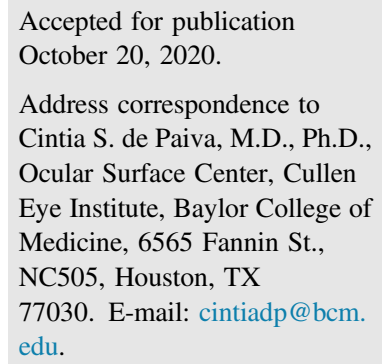

Oxidative stress occurs when cell antioxidants are unable to neutralize free radicals, usually generated by metabolic processes. ${ }^{1}$ Although the excess can damage the cells, maintaining a physiological oxidation-reduction level is fundamental for homeostasis. In healthy eyes, the controlled production of oxidants is vital in coordinating signaling pathways. ${ }^{2}$ Elevated levels of reactive oxygen species (ROS), markers of oxidative stress, and inflammatory cells were found in the conjunctiva and tear film in patients with Sjögren syndrome and different animal models of dry eye. Also, an oxidation-reduction imbalance is observed in other ocular dysfunctions, such as surface alterations, cataract, glaucoma, diabetic retinopathy, retinitis pigmentosa, toxic neuropathies, uveitis, and agerelated macular degeneration. ${ }^{3-5}$

In healthy young individuals, antioxidant enzymes neutralize low levels of ROS. The age-related increase in the
Supported by the National Institute of Health (NIH) National Eye Institute (NEI) EY030447 (C.S.D.P.) and EY028773 (J.C.), National Eye Institute training grant in vision sciences T32 EY007001 (H.H.), NIH/NEI EY002520 core grant (Vision Research Department of Ophthalmology), NIH CA125123 (Baylor Pathology and Histology Core), NIH National Institute of Allergy and Infectious Diseases P30AI036211, National Cancer Institute P30CA125123, and National Center for Research Resources S10RR024574 (Baylor Cytometry and Cell Sorting Core), Research to Prevent Blindness unrestricted grant (Department of Ophthalmology, Baylor College of Medicine), The Hamill Foundation (Ocular Surface Center), and The Sid Richardson Foundation (Ocular Surface Center). C.M.T.-V. received supplemental salary support from Facultad de Medicina, Universidad de Antioquia, Medellin, Colombia.

Disclosures: None declared.

Presented in part as abstracts at the following meetings: 2019 Oklahoma Geroscience Symposium (Oklahoma City, OK, April 24, 2019), Roy Huffington Aging Symposium (Houston, TX, January 21 to January 22, 2020), and Cornea and Ocular Surface Biology and Pathology, Gordon Research Conference (Barga, Italy, February 16 to February 21, 2020). 
levels of ROS, cell degradation, and a decrease in repair mechanisms contribute to the accumulation of oxidized molecules and the consequent formation of amyloid. ${ }^{6}$ Unlike the ocular surface, the lacrimal gland, although not repeatedly assaulted by environmental changes, also exhibits aging-related changes. The exposition to many external agents and a dysregulated immune system may contribute to an inadequate response against stressors throughout life, leading to inflammation and structural changes in the lacrimal gland. Oxidative stress in the lacrimal gland causes dysfunction in the tear film that contributes to the onset of dry eye, among other alterations. ${ }^{7}$

The nuclear factor erythroid derived-2-related factor 2 (Nrf2) is a transcription factor that regulates the expression of antioxidant and detoxification genes, protecting against oxidative stress caused by lesions or inflammatory processes. $^{8,9}$ Under conditions of oxidative stress, Nrf2 translocates to the nucleus, where it binds to promoter regions of a battery of antioxidant and detoxification genes, initiating antioxidative and repair processes. ${ }^{9,10}$ Cornea and conjunctival epithelia express $\mathrm{Nrf} 2$, and $\mathrm{Nrf} 2^{-/-}$mice are more sensitive to ocular alterations induced by acute tobacco smoke exposure. ${ }^{8}$

Many drugs that activate the Nrf2 antioxidant pathway have been studied to treat diseases caused by oxidative stress. Topical ocular treatment with antioxidant drugs has been shown to improve clinical signs and decrease inflammatory processes, oxidative stress markers, and ROS production on the ocular surface. ${ }^{11-17}$ Oltipraz is an organosulfur compound belonging to the class of dithioethiones with antioxidant properties through induction of Nrf2. ${ }^{18}$ Studies have reported oltipraz's ability to inhibit the growth of tumors in mice, as well as to reduce damage to liver DNA and induce enzymes to mediate detoxification processes. ${ }^{18,19}$

This study aimed to investigate oxidative stress pathways in aged lacrimal glands and test whether a diet with an Nrf2 inducer can modulate age-related dry eye disease.

\section{Materials and Methods}

The Institutional Animal Care and Use Committees at Baylor College of Medicine approved all animal experiments. All studies adhered to the Association for Research in Vision and Ophthalmology for the Use of Animals in Ophthalmic and Vision Research and to the NIH Guide for the Care and Use of Laboratory Animals. ${ }^{20}$ The experiments were performed at the Ocular Surface Center, Department of Ophthalmology, Baylor College of Medicine, Houston, TX.

\section{Animals}

Young breeder pairs of C57BL/6J mice were purchased from The Jackson Laboratory (Bar Harbor, ME) for establishing breeder colonies. Naturally aged female C57BL/6 mice were maintained in specific pathogen-free vivarium and were used at 2 to $3(n=20), 12(n=18), 15.5$ to 17 $(n=30), 18$ to $19(n=8), 21$ to $22(n=14)$, or 24 months of age $(n=24)$.

Young (aged 2 to 3 months; $n=22$ ) and middle-aged (aged 12 to 13 months; $n=29$ ) $\mathrm{Nrf}^{-1-}$ mice were compared with age-matched wild-type mice (young, $n=28$; middle aged, $n=20$ ). Tissues from $\mathrm{Nrf}^{-1-}$ and wild-type mice were initially a gift from Dr. Jiyang Cai (Department of Physiology, University of Oklahoma Health Sciences Center, Oklahoma City, OK), followed by transfer of mating pairs and establishment of breeding colonies at Baylor College of Medicine. Homozygous $\mathrm{Nrf} 2^{-/-}$mice have a mixed genetic background of C57BL/6/SV129. ${ }^{21}$ The correlation of human years to mouse days may vary according to the developmental stage. ${ }^{22}$ Mice aged 10 to 14 months can be considered middle aged (roughly 35 to 47 in human years), and mice aged 18 to 24 months can be considered old, aged, or elderly (roughly 56 to 69 human years), as these age intervals correlate with loss of reproductive function and decrease in life span, respectively. ${ }^{22,23}$

Mice were housed at specific pathogen-free facilities of Baylor College of Medicine and were kept on diurnal cycles of 12 hours light and 12 hours dark with ad libitum access to food and water. Because dry eye is more frequent in women, ${ }^{24,25}$ and aged male mice do not develop corneal barrier disruption (a hallmark of dry eye), ${ }^{26}$ only female mice were used. An effort was made to collect multiple tissues from each mouse. A final sample size per end point can be found in figure legends.

\section{Oltipraz Diet}

Oltipraz (4-methyl-5-pyrazinyl-3H-1,2-dithiole-3-thione) was purchased from Toronto Research Chemicals (Toronto, ON, Canada). A customized diet with $0.1 \%$ oltipraz was prepared by LabSupply (Fort Worth, TX). Thirty C57BL/6 female mice, aged 15.5 to 17 months, were randomized to receive either a standard diet (5V5R; Lab Supply) or oltipraz diet for 8 weeks $(n=15$ per diet). Mice were weighed weekly, and body mass was recorded. At the end of the eighth week, they were euthanized, and tissues were collected and processed.

\section{RNA Isolation and Real-Time PCR}

Total RNA from lacrimal glands was extracted using a QIAGEN RNeasy Plus Mini RNA isolation kit (Qiagen, Hilden, Germany) following the manufacturer's protocol. After isolation, RNA concentration was measured, and cDNA was synthesized using the Ready-To-Go You-Prime First-Strand kit (GE Healthcare, Chicago, IL). Real-time PCR was performed using specific TaqMan minor groove binder probes for IL-1 $\beta$ (Illb; Mm00434228), major histocompatibility complex class II (MHC II; Mm00482914), interferon (IFN)- $\gamma$ (Ifng; Mm00801778), tumor necrosis factor (TNF)- $\alpha$ (TNF $\alpha$; Mm00443258), cathepsin S (Ctss; 
Mm00457902), glutathione S-transferase P (GST-P1; Mm04213618), CD19 (CD19; Mm00515420), and TaqMan Universal PCR Master Mix AmpErase UNG in a commercial thermocycling system (StepOnePlus Real-Time PCR System; Applied Biosystems/Thermo Fisher Scientific, Foster City, CA), according to the manufacturer's recommendations. The hypoxanthine phosphoribosyltransferase 1 (HPRT1; Mm00446968) gene was used as an endogenous reference for each reaction. The quantitative PCR results were analyzed by the comparative $\mathrm{Ct}$ method and were normalized by the $\mathrm{Ct}$ value of HPRT $1 .^{27}$ The young group served as calibrator.

\section{Histology, Periodic Acid-Schiff Staining, Immunohistochemistry, and Quantification of Focus Score}

Eyes and ocular adnexa were excised, fixed in $10 \%$ formalin, paraffin embedded, and cut into sections $(5 \mu \mathrm{m}$ thick) using a microtome (Microm HM 340E; Thermo Fisher Scientific, Waltham, MA). Sections cut from paraffin-embedded globes were stained with periodic acidSchiff reagent. The goblet cell density was measured in the superior and inferior bulbar and tarsal conjunctiva using NIS-Elements software AR, version 5.20.2 (Nikon, Melville, NY) and expressed as the number of positive cells per millimeter. ${ }^{28}$

Immunofluorescence was performed to detect nitrotyrosine (1:100; catalog number 306507; RD Systems, Minneapolis, MN) and phosphorylated NF-кB p65 (1:100; Abcam, Cambridge, MA; catalog number ab106129) antibodies using cold acetone fixation and $20 \%$ goat serum as blocking solution. Secondary goat anti-rabbit Alexa-Fluor 488 conjugated IgG antibodies were used, as previously described. ${ }^{29}$ The images were captured by an Eclipse E400 Nikon fluorescence microscope equipped with a DS-F1 digital camera.

Immunohistochemistry was performed to detect IL-1 $\beta$ (1:100; rabbit monoclonal clone D4T2D; Cell Signaling Technology, Danvers, MA; catalog number 12426S), MHC II (1:100; I-A/I-E; clone M5/114.15.2; BD Pharmingen, San Diego, CA; catalog number 556999), TNF- $\alpha$ (1:00 dilution; rabbit monoclonal antibody; clone D2D4; Cell Signaling Technology; catalog number 11948), or cathepsin S (1:00 dilution; Santa Cruz Biotechnology, Dallas, TX; catalog number sc-271619) antibodies and appropriate biotinylated secondary antibodies (BD Biosciences, San Diego, CA) and a Vectastain Elite ABC kit using NovaRed reagents (Vector Laboratories, Burlingame, CA), as previously described. ${ }^{30}$

Lymphocytic infiltration foci were counted in hematoxylin and eosin-stained lacrimal gland sections by standard light microscopy using a $10 \times$ objective (Nikon; Eclipse E400) by two masked observers. A minimum of 50 mononuclear cells was counted as one focus, and the total number of foci per gland was recorded. Slides were scanned to obtain digital images using PathScan Enabler
V (Meyer Instruments, Houston, TX) and were calibrated according to the manufacturer's instructions $(2.54 \mu \mathrm{m} /$ pixel) using NIS Elements software. The total area of the lacrimal glands was measured using the autodetect area function of the Nikon Elements software or was manually circumscribed using the polyline function. Finally, focus scores were calculated by dividing the number of foci per $\mathrm{mm}^{2}$ and quantifying the number of inflammatory cell foci per $4 \mathrm{~mm}^{2}$ tissue area.

\section{Measurement of Corneal Barrier Function}

Corneal barrier function was assessed by quantifying corneal epithelial permeability to $70-\mathrm{kDa}$ Oregon Green Dextran-488 (Invitrogen, Carlsbad, CA), according to a previously published protocol, ${ }^{31}$ with modifications. Briefly, $1 \mu \mathrm{L}$ of a $50 \mathrm{mg} / \mathrm{mL}$ solution of Oregon Green Dextran-488 was instilled onto the ocular surface 1 minute before euthanasia. Corneas were rinsed with $2 \mathrm{~mL}$ of phosphatebuffered saline and imaged with a stereoscopic zoom microscope (model SMZ 1500; Nikon), under fluorescence excitation at $470 \mathrm{~nm}$. Images were acquired with an LED Lumecor Light source and a high-speed, high-sensitivity Zyla Camera (Andor, Oxford Instrument, Abingdon, UK) and a 488-nm filter. Oregon Green Dextran-488 staining intensity was graded in digital images by measuring the mean fluorescence intensity within a 2-mm diameter circle placed on the central cornea using NIS Elements software version AR, 5.20.02 by two masked observers. The mean intensity of the right and left eyes was averaged, and the mean average from biological replicates was calculated and analyzed.

\section{Measurement of NF- $\kappa$ B Levels}

Lacrimal glands were excised and lysed to extract cytoplasmic and nuclear proteins with a nuclear extraction kit and stored at $-80^{\circ} \mathrm{C}$ until use. NF- $\mathrm{B}$ p65 activation was quantitatively measured by a TransAM NF- $\kappa B$ p65 that specifically quantifies phosphorylated NF- $\kappa \mathrm{B}$ p65 and total NF- $\kappa \mathrm{B}$ p65, according to the manufacturer's protocol (Active Motif, Carlsbad, CA; catalog number 40596). Nuclear or whole-cell protein lysates from young and aged $(50 \mu \mathrm{g})$ mice were added to wells of a 96-well plate to which an oligonucleotide containing the NF- $\kappa \mathrm{B}$ consensus site had been immobilized. The active form of NF- $\kappa \mathrm{B}$ contained in nuclear specimens of whole-cell extract binds explicitly to this oligonucleotide. After incubation with a horseradish peroxidase-conjugated secondary antibody and colorimetric developing solution, the absorbance was read at $450 \mathrm{~nm}$ with a reference wavelength of $655 \mathrm{~nm}$ by using a colorimetric plate reader (Tecan Infinite M200; Magellan V6.55 software; Tecan, Männedorf, Switzerland). Results are presented as the ratio of NF- $\kappa B$ p65 phosphorylated at serine 536/total NF-кB p65. 
Tear Washings and Multiplex Cytokine Immunobead Assay

Tear washings were collected from live 2- to 3-, 12-, and 24month-old mice. Briefly, $1.5 \mu \mathrm{L}$ of phosphate-buffered saline $+0.1 \%$ bovine serum albumin was instilled into the conjunctival sac. The tear fluid and buffer were collected with a $1-\mu \mathrm{L}$ volume glass capillary tube (Drummond Scientific Co, Broomhall, PA) by capillary action from the tear meniscus in the lateral canthus and stored at $-80^{\circ} \mathrm{C}$ until the assay was performed. One sample consisted of tear washings from both eyes of two mice pooled $(4 \mu \mathrm{L})$ in phosphate-buffered saline $+0.1 \%$ bovine serum albumin $(6$ $\mu \mathrm{L})$. Seven to 18 samples per group were divided into four independent experiments.

Samples were added to wells containing the appropriate cytokine bead mixture that included mouse monoclonal antibodies specific for IFN- $\gamma$, IL-17, IL-13, IL-12p70, vascular endothelial growth factor (VEGF), IL-1 $\beta$, TNF- $\alpha$, and chemokine (C-C motif) ligand 2 (Millipore, Burlington, MA; catalog number MCYTOMAG-70K), as previously reported. ${ }^{32}$ The reactions were detected with streptavidinphycoerythrin using a Luminex 100 IS 2.3 system (Austin, TX). The minimum limit of detection for this assay was $0.3 \mathrm{pg} / \mathrm{mL}$ for VEGF, $0.5 \mathrm{pg} / \mathrm{mL}$ for IL-17, $1.1 \mathrm{pg} / \mathrm{mL}$ for IFN- $\gamma, 2.3 \mathrm{pg} / \mathrm{mL}$ for TNF- $\alpha, 4.8 \mathrm{pg} / \mathrm{mL}$ for IL-12p70, 5.4 $\mathrm{pg} / \mathrm{mL}$ for IL-1 $\beta, 6.7 \mathrm{pg} / \mathrm{mL}$ for chemokine (C-C motif) ligand 2, $7.8 \mathrm{pg} / \mathrm{mL}$ for IL-13, and $12.8 \mathrm{pg} / \mathrm{mL}$ for IL-13. Results are presented as means $\pm \mathrm{SD}(\mathrm{pg} / \mathrm{mL})$.

\section{Flow Cytometry Analysis}

Lacrimal glands were excised and incubated with $0.1 \%$ collagenase IV, as previously described. ${ }^{33}$ Draining nodes were excised and prepared, as previously described. ${ }^{34}$ Single-cell suspensions were incubated with anti-CD16/32 $\left(4^{\circ} \mathrm{C} ; 10\right.$ minutes), and subsequently stained into three different panels: panel 1: MHC II (clone I-A/I-E; BD Pharmingen); panel 2: CD45 (clone 30F11; BD Biosciences, San Diego, CA) and IFN- $\gamma$ (clone XMG1.2; Biolegend, San Diego, CA); and panel 3: CD45 and CD4 (clone GK1.5; BD Biosciences).

For IFN- $\gamma$ intracellular staining, single-cell suspensions were incubated for 5 hours in the presence of $5 \% \mathrm{CO}_{2}$ with 0.5 $\mu \mathrm{L}$ Golgi Stop (BD Biosciences), $0.5 \mu \mathrm{L}$ Golgi Plug (BD Bioscience), phorbol myristate acetate $(0.5 \mu \mathrm{g}$; SigmaAldrich, St. Louis, MO), and ionomycin (0.5 $\mu \mathrm{g}$; Sigma, St. Louis, MO) in $1 \mathrm{~mL}$ complete RPMI 1640 medium. Cells were stained with an infrared fluorescent viability dye (Life Technologies, Grand Island, NY) before incubation with a fixation/permeabilization working solution (Ebiosciences/ Thermofisher, Waltham, MA) for 18 hours, followed by incubation with anti-IFN- $\gamma_{-}$Pacific Blue and antiCD45_Alexa Fluor 700.

The gating strategy was as follows: lymphocytes were identified by forward scatter area and side scatter area gates, followed by two singlet gates (forward scatter height versus forward scatter area and side scatter height versus side scatter area) followed by live/dead identification using propidium iodide. Alive cells were either plotted for MHC II expression or by $\mathrm{CD}_{4} 5^{+}$gate and identification of $\mathrm{CD} 45^{+} \mathrm{IFN}-\gamma$ cells. Negative controls consisted of fluorescence minus one splenocytes.

Cells were acquired with either BD LSR II or BD Canto II Benchtop cytometer with BD Diva software version 6.7 (BD Biosciences). At least 100,000 events or more were collected. Final data were analyzed using FlowJo software version 10 (Tree Star Inc., Ashland, OR).

\section{Western Blot Analysis}

Lacrimal glands were surgically excised and lysed in radioimmunoprecipitation assay lysis buffer (Thermo Fisher, Waltham, MA; catalog number 89900) plus protease inhibitor cocktail (Sigma; catalog number P8340). Protein concentration was measured using a micro BCA protein assay kit (Thermo Fisher; catalog number 23235). Lacrimal gland extracts $(50 \mu \mathrm{g})$ were resuspended in SDS sample buffer, boiled for 5 minutes, and analyzed on $4 \%$ to $15 \%$ miniprotean TGX stain-free gels (Bio-Rad, Hercules, CA; catalog number 4568084). The proteins were electrophoretically transferred to polyvinylidene difluoride membranes (BioRad; catalog number 170-4157). The blots were probed with an anti-nitrotyrosine antibody $(2 \mu \mathrm{g} / \mathrm{mL}$; ThermoFisher; catalog number A21285), anti-4-hydroxynonenal (4-HNE) antibody ( $0.5 \mu \mathrm{g} / \mathrm{mL}$; Abcam; catalog number ab48506), or anti- $\beta$ actin antibody (Sigma; catalog number A5441) overnight at $4^{\circ} \mathrm{C}$. The blots were washed extensively with a solution containing $50 \mathrm{mmol} / \mathrm{L}$ Tris, $\mathrm{pH} 8.0,138 \mathrm{mmol} / \mathrm{L}$ $\mathrm{NaCl}, 2.7 \mathrm{mmol} / \mathrm{L} \mathrm{KCl}$, and $0.05 \%$ Tween 20 . The antigenantibody complexes were detected by the ECL plus Western Blotting Detection System (GE Healthcare, Chicago, IL; catalog number RPN2106) using horseradish peroxidase-conjugated goat anti-mouse IgG as a secondary antibody. Images were taken by ChemiDoc Touch Imaging Systems (Bio-Rad), and band densities were measured by Bio-Rad software (Image Lab version 6.0; Bio-Rad).

\section{Statistical Analysis}

The sample size was calculated with StatMate2 Software (GraphPad Software, San Diego, CA) based on pilot studies. Statistical analyses were performed with Graph Pad Prism software version 8 (GraphPad Software). Data were first evaluated for normality with the Kolmogorov-Smirnov normality test. Appropriate parametric ( $t$-test) or nonparametric ( $U$-test) statistical tests were used to make comparisons between two age groups. Whenever adequate, one- or two-way analysis of variance or Kruskal-Wallis followed by post hoc tests were used. All experiments were repeated at least once. The final sample per experiment is shown in the figure legends. 


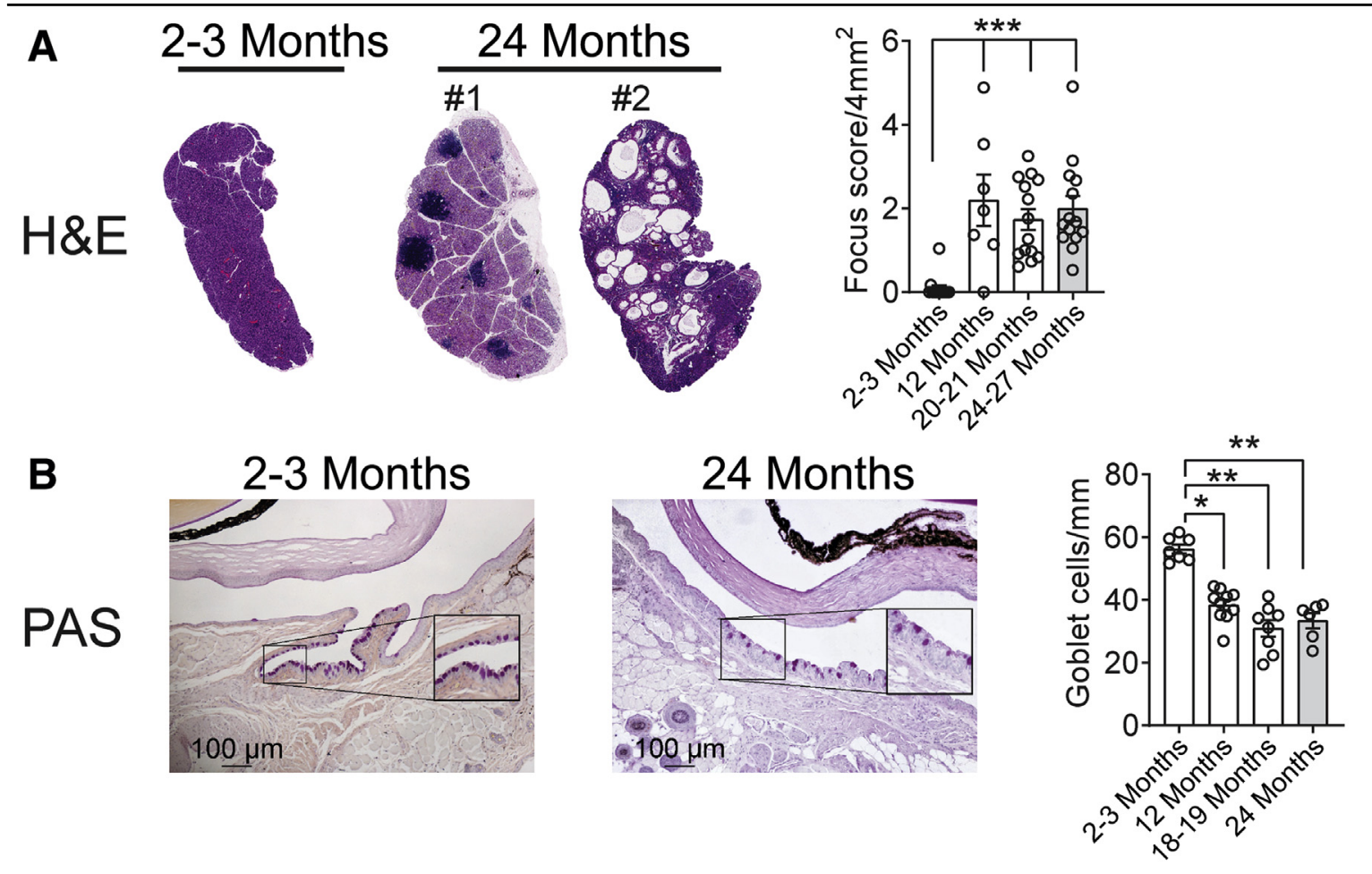

\section{2-3 Months 24 Months 24 Months-NC D}

$N F-\kappa B$

phosphorylated p65

\section{NF-кB}

phosphorylated p65 + DAPI
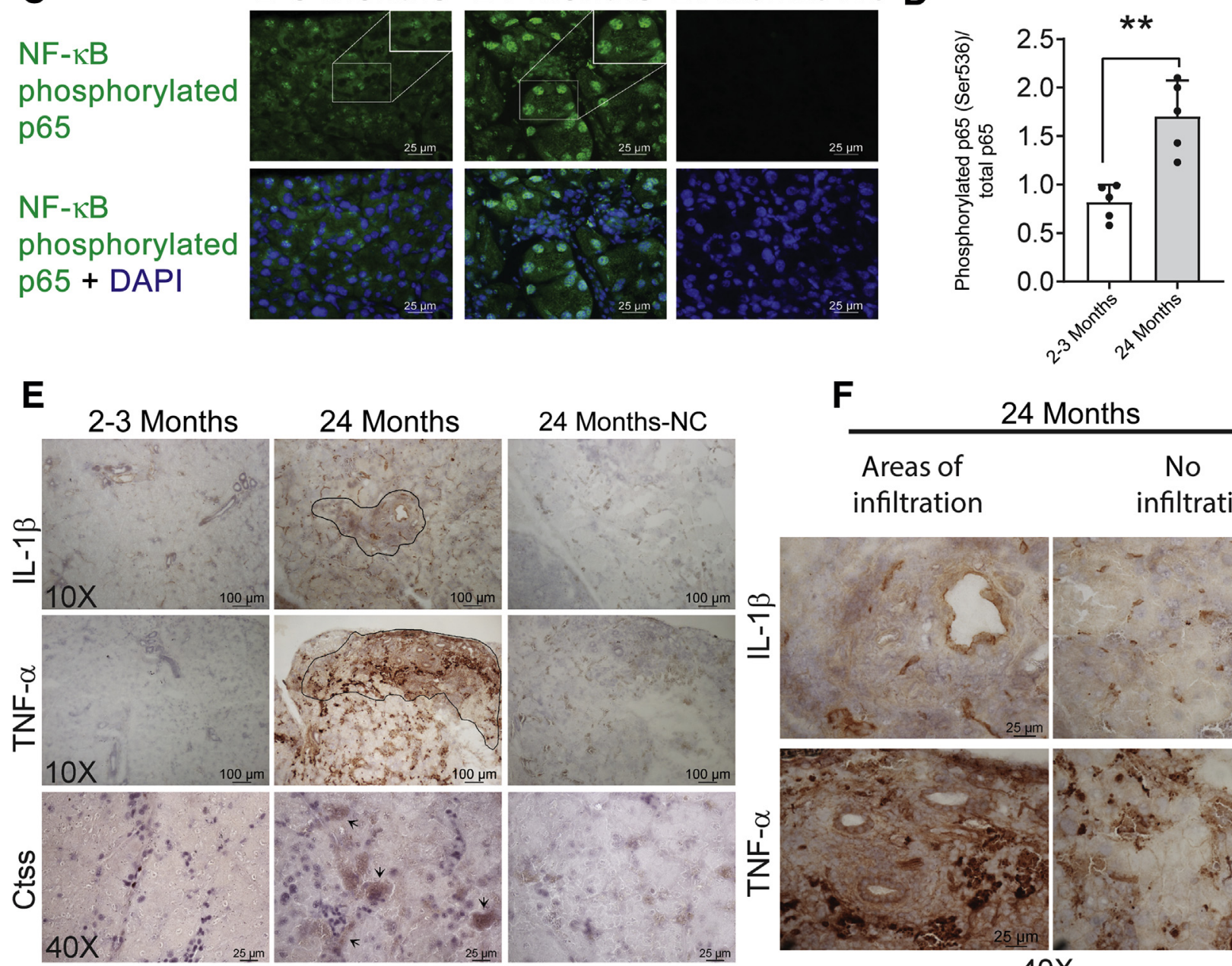

$\mathbf{F}$

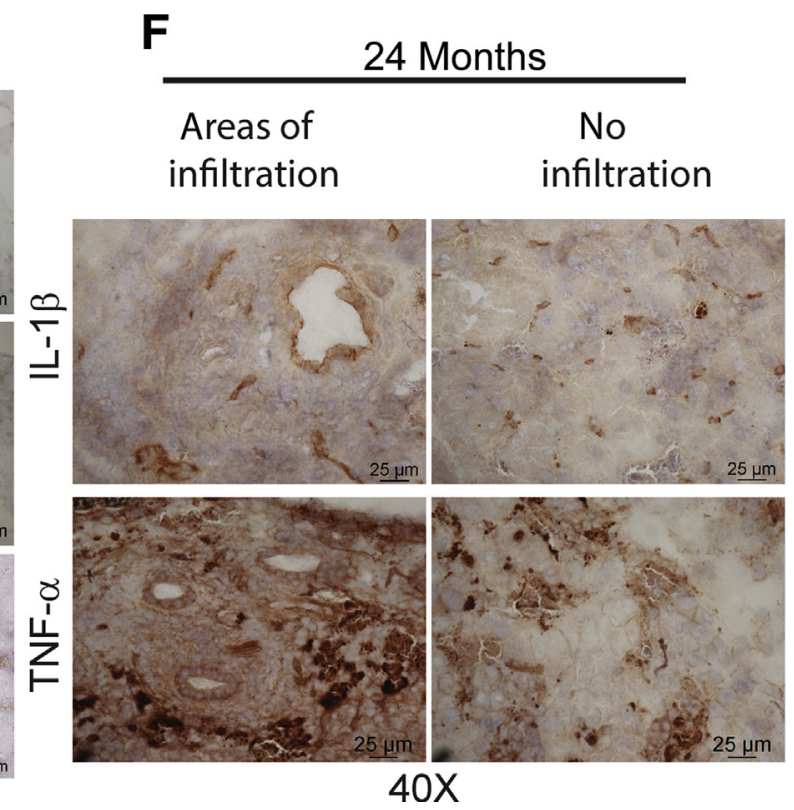




\section{Results}

\section{Increased Inflammation in the Aged Lacrimal Gland}

Aging is a significant risk factor for dry eye disease. A state of low-grade inflammation has been described as inflammaging and reported in humans with increased age. ${ }^{35}$ Proir publications from our laboratory have shown that aged C57BL/6 mice spontaneously develop dry eye, recapitulating the human disease. ${ }^{26,36}$ In the present study, lacrimal glands were collected from C57BL/6J mice aged 2 to 3,12 , 20 , and 24 months, or older. Histologic evaluation of aged lacrimal glands showed frequent periductal infiltration and presence of lymphocytic infiltrates, sometimes organized in concentric features (Figure 1A). Enlarged epithelial ducts and moderate to extensive tissue destruction of the cases were observed in about $20 \%$ to $30 \%$ of mice, confirming previous reports. ${ }^{37,38}$ The focus score method was used to quantify the lacrimal gland lymphocytic infiltration in hematoxylin and eosin histologic sections (Materials and Methods). Lacrimal gland lymphocytic infiltration was quantified using the focus score method in hematoxylin and eosin histologic sections. There was a significant increase in focus score in 24-month-old mice compared with young mice (Figure 1A). Lacrimal gland sections with extensive epithelial ducts were not included in the evaluation. Goblet cell loss is one of the hallmarks of dry eye disease. Conjunctival goblet cell density was investigated in animals of different ages. There was a significant decrease in goblet cell density as mice aged, noted as early as 12 months of age (Figure 1B).

NF- $\kappa \mathrm{B}$ is a master regulator of inflammation. An agerelated increase in p65 NF- $\kappa \mathrm{B}$ has been reported in aged lacrimal glands of rats. ${ }^{39}$ We hypothesized that NF- $\kappa B$ might also be increased in the murine aged lacrimal gland. Using a specific NF- $\kappa \mathrm{B}$ phosphorylated p65 antibody, nuclear translocation of p65 was observed in lacrimal gland acinar cells (Figure 1C), quantified using a TransAM NF- $\kappa$ B kit. There was an increased phosphorylated p65/total p65 NF- $\kappa \mathrm{B}$ ratio in 24-month-old compared with young lacrimal gland lysates (Figure 1D).
Next, inflammatory and type 1 helper T-cell-related cytokines were investigated by immunohistochemistry, realtime PCR, and flow cytometry. There was an increase in IL$1 \beta$, TNF- $\alpha$, and cathepsin $\mathrm{S}$ immunoreactivity in aged lacrimal glands (Figure 1E). Interestingly, high IL-1 $\beta$ and $\mathrm{TNF}-\alpha$ protein expression levels were observed in the ductal epithelial cells and immune cells in the areas of lymphocytic infiltration (Figure 1E); however, immunoreactivity in immune cells was also observed in areas without infiltration. Cathepsin S immunoreactivity was seen in between acinar cells (Figure 1E). A significant increase in $M H C I I, I F N-\gamma$, $I L-1 \beta, T N F-\alpha$, and cathepsin $S$ transcript levels was observed in the aged lacrimal gland (Figure 2A). Increased MHC II and IFN- $\gamma$ protein levels were also found in aged lacrimal gland lysates compared with young lysates, using flow cytometry (Figure 2B). Published studies from our laboratory have also shown increased IFN- $\gamma$ expression in the conjunctiva at protein and mRNA levels. ${ }^{26,36,37}$

A tear profile moving toward an inflammatory milieu has also been seen in patients with dry eye and aged healthy subjects. ${ }^{40-42}$ To investigate if aged mice have the same inflammatory phenotype in tears as previously described in humans, ${ }^{42}$ an array of inflammatory/immune cytokines (IFN- $\gamma$, IL-17, IL-13, IL-12p70, IL-1 $\beta$, TNF- $\alpha$, chemokine (C-C motif) ligand 2, and VEGF) was investigated in tears of young, middle-aged, and aged mice. Assays were performed on four independent sets of tears, and results were averaged. The measured concentrations of these cytokines are shown in Figure 2C. There was a progressive increase in IFN- $\gamma$ and IL-12p70 as mice aged, whereas there was a sharp decrease in VEGF levels at 12 and 24 months (Figure 2A). IL-17A levels were low in young mice and remained low at all ages. IL- $1 \beta$, TNF- $\alpha$, and IL-13 results were below the detection levels and are not shown.

These results indicate that aged C57BL/6 mice spontaneously developed inflammation, a mechanism that may be mediated by NF- $\kappa \mathrm{B}$ activation in the lacrimal gland. Inflammatory markers can be identified in tears of aged mice, which have the potential to cause further harm to the ocular surface.

\footnotetext{
Figure 1 Increased inflammatory markers in the aged lacrimal gland. A: Representative lacrimal gland sections of young (2 to 3 months) and aged (24 months) C57BL/6 female mice stained with hematoxylin and eosin (H\&E), which were used to calculate the focus scores in the graph. Note evident areas of infiltration in 24-month-old female 1. Ductal dilation and loss of acinar cells is present in about $20 \%$ of cases (as in 24-month-old 2); these glands were not included in the accumulative graph. Kruskal-Wallis test was used, followed by the Dunn multiple comparison test. B: Representative conjunctival sections stained with periodic acid-Schiff (PAS; purple/magenta) from young and aged mice. Insets: High magnifications of the boxed areas demarcated. Accumulative data of goblet cell density measured in the conjunctiva of mice at different ages. Kruskal-Wallis test was used, followed by the Dunn multiple comparison test. C: Representative immunofluorescence image of young and aged lacrimal gland, showing increased NF- $\kappa$ B phosphorylated p65 translocation (green) and DAPI (blue; nuclei counterstaining) in aged acinar tissue. Insets: High magnifications of the boxed areas demarcated. D: NF- $\kappa$ B activity (phosphorylated p65/total p65) measured in cellular fractions of lacrimal glands using a TransAM NF- $\kappa B$ p65 kit (Active Motif); U-test was used. E: Representative immunohistochemistry images stained for IL- $\beta$, tumor necrosis factor (TNF)- $\alpha$, and cathepsin S (Ctss; red) in young and aged lacrimal gland. Areas of lymphocytic infiltration in aged sections are circumscribed. F: Representative images of 24-month-old lacrimal gland stained for IL- $\beta$ and TNF- $\alpha$ (red), showing immunoreactivity in areas with and without lymphocytic infiltration. $n=14$ mice aged 2 to 3,20 to 21 , and 24 months (A); $n=7$ mice aged 12 months (A); $n=7$ mice aged 2 to 3 months (B); $n=10$ mice aged 12 months (B); $n=9$ mice aged 18 to 19 months (B); $n=6$ mice aged 24 months (B); $n=4$ to 5 per age (D). * $P<0.05$, ${ }^{*} P<<0.01$, and ${ }^{* *} P<0.001$. Scale bars: $100 \mu \mathrm{m}$ (B and $\mathbf{E}$, top and middle panels); $25 \mu \mathrm{m}$ (C, E, bottom panel, and $\left.\mathbf{F}\right)$. Original magnification, $\times 10$ (E, top and middle panels); $\times 40(\mathrm{E}$, bottom panel, and $\mathbf{F})$. NC, negative control.
} 
A

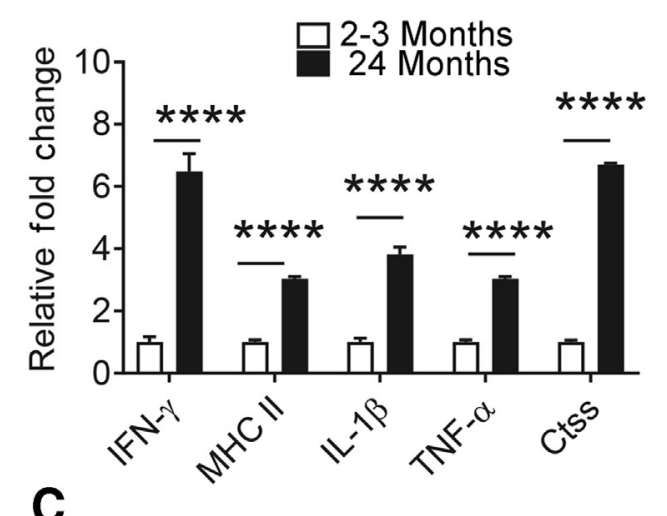

B

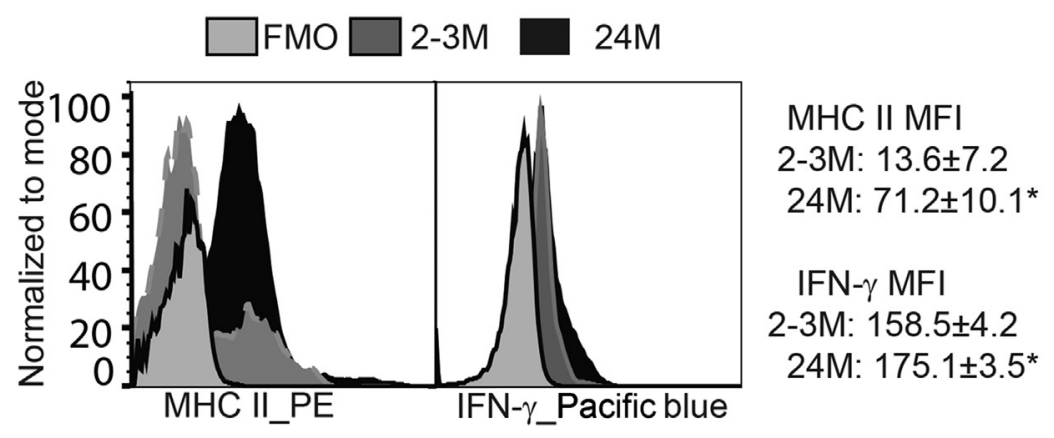

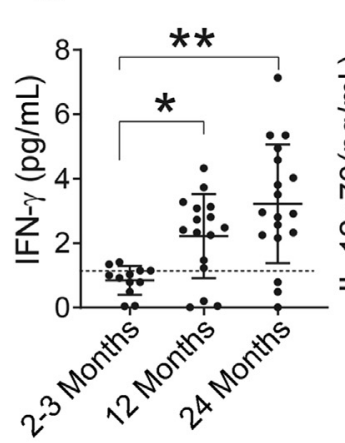
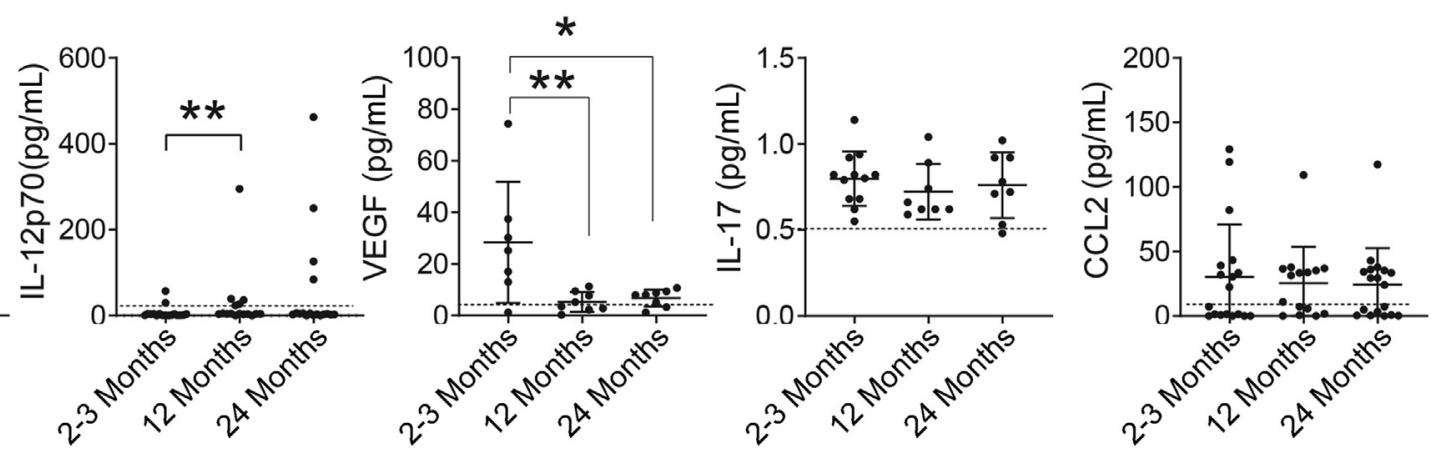

Figure 2 Altered inflammatory cytokines in lacrimal gland lysates and tears of aged mice. A: Relative fold expression changes of major histocompatibility complex II (MHC II), interferon- $\gamma($ IFN- $\gamma)$, IL-1 $\beta$, tumor necrosis factor- $\alpha$ (TNF- $\alpha$ ), and cathepsin S (Ctss) in 2- to 3- and 24-month-old lacrimal glands. U-test was used. B: Representative flow cytometry histograms showing increased expression of MHC II and IFN- $\gamma$ in lacrimal gland lysates. The gating strategy was as follow: lymphocytes were identified by forward scatter area (FSC-A) and side scatter area (SSC-A) gates, followed by two singlet gates (FSC height versus FSC-A and SSC height versus SSC-A), followed by live/dead identification using propidium iodide. Alive cells were either plotted for MHC II expression or followed by $\mathrm{CD} 45^{+}$gate and identification of $\mathrm{CD} 45^{+} \mathrm{IFN}-\gamma$ cell ${ }^{+}$cells. $U$-test was used. C: Tear washings were collected from young (2 to 3 months), middle-aged (12 months), and aged mice (24 months). Cytokines were investigated using multiplex assay. Mean concentration of IFN- $\gamma$, IL12p70, vascular endothelial growth factor (VEGF)-A, IL-17, and chemokine (C-C motif) ligand 2 (CCL2); one sample equals pooled tear washings from four eyes. Three to four independent experiments were pooled; $U$-test was used. $n=5$ left lacrimal glands per age (A); $n=5$ right lacrimal glands per age (B); $n=7$ to 18 samples per age (C). ${ }^{*} P<0.05,{ }^{* *} P<0.01$, and ${ }^{* * * *} P<0.0001$. FM0, fluorescence minus one; MFI, median fluorescence intensity.

\section{Increased Oxidative Stress in the Aged Lacrimal Gland}

Oxidative stress damage occurs when levels of antioxidants are imbalanced with ROS formation. Increased oxidative stress levels have been reported in the conjunctiva of Sjögren syndrome patients. ${ }^{43,44} \mathrm{We}$ investigated the levels of oxidative stress in lacrimal glands using markers for protein nitration (nitrotyrosine) and lipid peroxidation (4-HNE) by immunostaining and Western blot analysis. The immunoreactivity to nitrotyrosine was negative within the lymphocytic infiltration areas, but it was concentrated in the acinar cells of the aged lacrimal gland (Figure 3A). Minimal immunoreactivity to nitrotyrosine was observed in the lacrimal glands of young mice. Western blots of total cell lysates from the aged lacrimal glands showed increased nitrotyrosine and 4-HNE intensity band levels in the 24-month-old compared with the young group $(P<0.05)$ (Figure 3B-C). These results confirm that oxidative stress levels are elevated in the aged lacrimal gland.

\section{$\mathrm{Nrf2}^{-/-}$Mice Have Increased Age-Related Dry Eye Disease}

There are many antioxidant defenses, such as the superoxide dismutase and the Nrf2 antioxidant systems. Evidence in the literature shows that superoxide dismutase $^{-l-}$ mice develop lacrimal gland infiltration and acinar apoptosis around 1 year of age. ${ }^{45}$ The effects of Nrf2 deletion were investigated in aged lacrimal gland and the ocular surface. $\mathrm{Nrf} 2^{-1-}$ mice with a mixed C57BL/SV129 background ${ }^{21}$ were compared with their wild-type littermates. Female mice were used at 2 to 3 and 12 to 13 months of age (middle age). Histologic evaluation in hematoxylin and eosin-stained sections showed a significantly increased focus score in both young and middle-aged $\mathrm{Nrf} 2^{-/-}$lacrimal gland when compared with those of agematched wild type lacrimal glands (Figure 4A).

Furthermore, greater focus scores, a measurement of lacrimal gland infiltration, were observed in middle-aged $\mathrm{Nrf} 2^{-/-}$compared with middle-aged wild-type mice. 
A

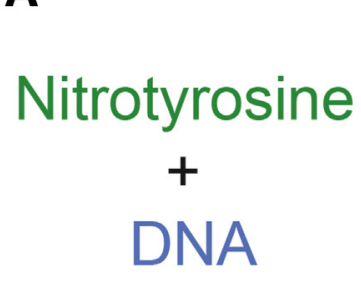

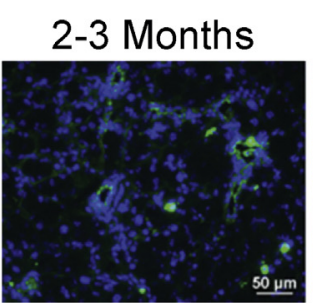

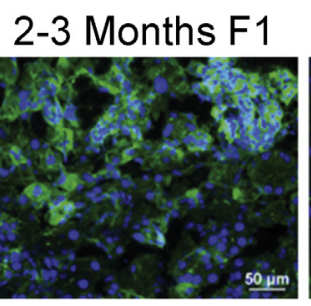

2-3 Months-Negative
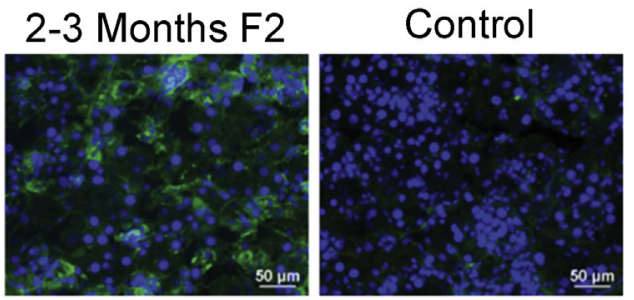

B

\section{2-3 Months $\frac{24 \text { Months }}{1+2+3}$}
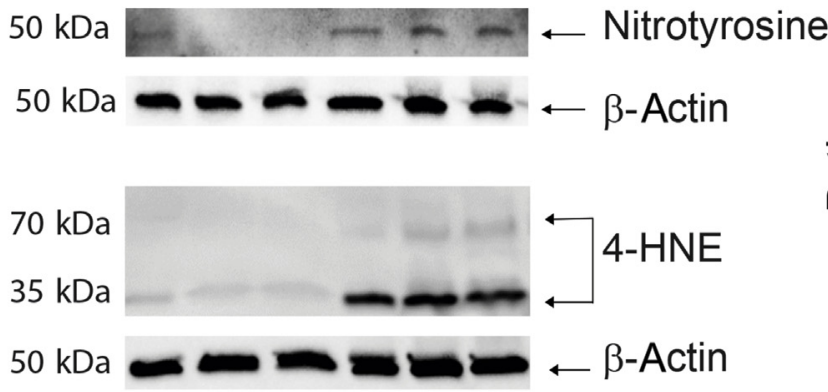

C

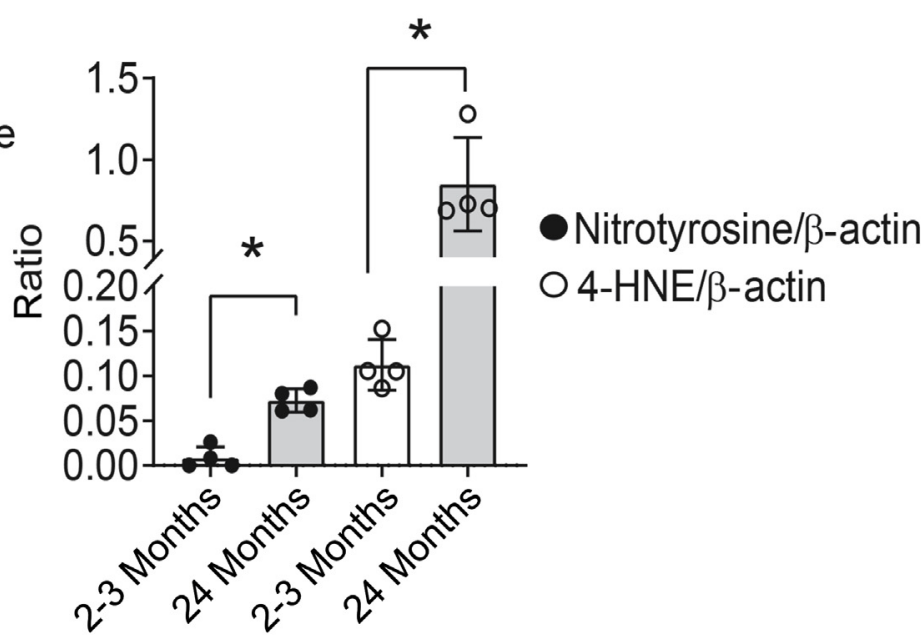

Figure 3 Increased oxidative stress markers in the aged lacrimal gland. A: Representative images of lacrimal glands from young (2 to 3 months) and aged (24 months) C57BL/6 female (F) mice stained for nitrotyrosine (green) and DAPI (blue; nuclei counterstaining), showing sections from two different animals (F1 and F2). B: Western blot analysis for nitrotyrosine, 4-hydroxynonenal (4-HNE), and $\beta$-actin in three different biological samples from young and elderly lacrimal gland lysates. C: Densitometry is showing nitrotyrosine/ $\beta$-actin or $4-\mathrm{HNE} / \beta$-actin ratio. $U$-test was used. ${ }^{*} P<0.05$. Scale bar $=50 \mu \mathrm{m}(\mathbf{A})$.

Evaluation of conjunctival goblet cell density showed that $\mathrm{Nrf} 2^{-1-}$ mice had comparable age-related goblet cell loss (Figure 4B). There was no difference in the focus score between virgin and retired breeder middle-aged mice (data not shown). This indicates that progressive accumulation of unbalanced ROS has a deleterious and accentuated effect in the lacrimal gland. Next, the uptake of a fluorescent dye was investigated as a measurement of corneal permeability, a hallmark of dry eye disease in humans. Data in Figure $4 \mathrm{C}$ show a significant age-related increase in corneal permeability in both wild-type and $\mathrm{Nrf}^{-/-}$mice at 12 to 13 months of age; however, there was a more significant corneal barrier disruption in the $\mathrm{Nrf}^{-1-}$ group.

Increased mRNA levels of $I L-1 \beta, M H C I I$, and $I F N-\gamma$ mRNA were observed in the lacrimal glands of young $\mathrm{Nrf}^{-1-}$ compared with those of young wild-type mice, and greater $I L-1 \beta, M H C I I, T N F-\alpha, I F N-\gamma$, and cathepsin $S$ mRNA transcripts were found in the lacrimal glands of middle-aged $\mathrm{Nrf}^{-/-}$mice compared with those of wild-type mice of the same age (Figure 4D). These results indicate that imbalanced and increased oxidative pathways can profoundly alter the lacrimal gland health status with aging by promoting increased inflammaging and tissue infiltration. These results also indicate that Nrf2 is a crucial pathway, controlling oxidative stress with aging within the lacrimal glands.

\section{An Nrf2-Inducer Diet Improves Age-Related Dry Eye}

Diet components can modulate oxidative stress; for example, the blueberry component pterostilbene protects corneal epithelial cells from hyperosmolarity-induced oxidative stress. ${ }^{15}$ A diet with $0.1 \%$ oltipraz, given to 18 month-old mice for 2 weeks, improved age-related oxidative stress in the liver. ${ }^{19}$ An investigation of an Nrf2-inducing diet in aged mice was therefore performed in this study. To accomplish this, 15.5- to 17-month-old C57BL/6 mice were randomized to receive either a standard diet or a diet containing $0.1 \%$ oltipraz for 8 weeks (Figure 5A). The only difference in the diet was the addition of oltipraz.

Tissues were collected after euthanasia when mice were 17.5 to 19 months old. Mice were weighed weekly; there was no difference in the body mass at either the beginning or the end of the study (data not shown). Western blots of lacrimal gland lysates collected after treatment showed that nitrotyrosine and 4-HNE levels were decreased in the 
A

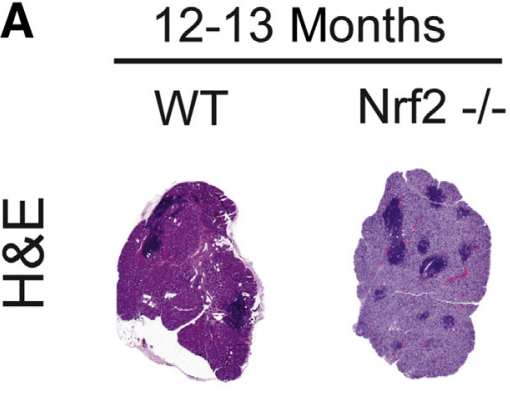

B

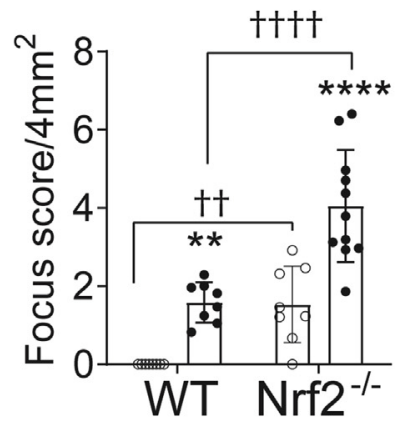

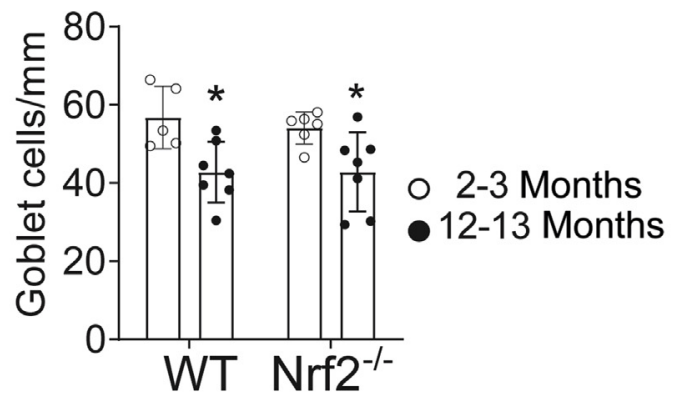

\section{C $\quad 2-3$ Months $12-13$ Months}
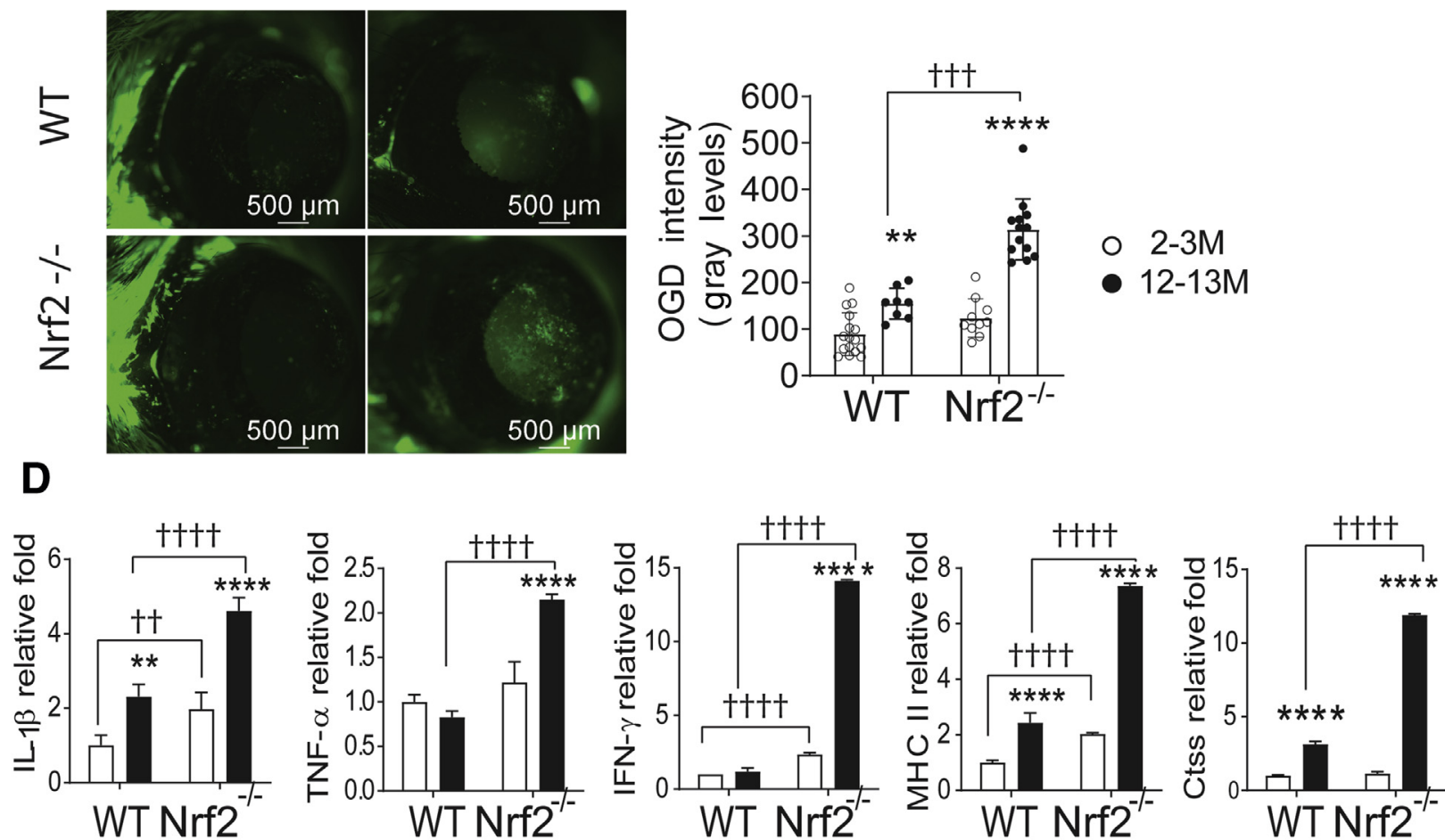

Figure 4 Nuclear factor erythroid derived-2-related factor $2(\mathrm{Nrf2})^{-/-}$mice have more severe age-related dry eye disease. A: Representative lacrimal gland sections stained with hematoxylin and eosin (H\&E), showing increased focus score in Nrf2 ${ }^{-1-}$ mice compared with age-matched wild-type (WT) mice; two-way analysis of variance was used, followed by the Sidak post hoc test. B: Accumulative data of goblet cell density measured in the conjunctiva of WT and $\mathrm{Nrf2}^{-1-}$ mice. Each dot is one animal. Kruskal-Wallis test was used, followed by the Dunn multiple comparison test. C: Representative images of corneas stained with Oregon Green Dextran-488 (OGD) in young and middle-aged Nrf2 and WT mice. Accumulative data on the graph; each dot is one animal (average of right and left eyes). Kruskal-Wallis test was used, followed by the Dunn multiple comparison test. D: Relative fold expression of $I L-1 \beta$, tumor necrosis factor$\alpha(T N F-\alpha)$, major histocompatibility complex II (MHC II), interferon- $\gamma$ (IFN- $\gamma)$, and cathepsin S (Ctss) mRNA transcripts in 2- to 3- and 12- to 13-month-old WT and $\mathrm{Nrf2}^{-1-}$ lacrimal glands. Two-way analysis of variance was used, followed by the Sidak post hoc test. $n=4$ to 5 per group (D). ${ }^{*} P<0.05,{ }^{*} P<0.01$, and ${ }^{* * *} P<0.0001$ for age comparison within the same strain; ${ }^{\dagger \dagger} P<0.01,{ }^{\dagger \dagger} P<0.001$, and ${ }^{\dagger \dagger \dagger \dagger} P<0.0001$ for interstrain comparison (as shown). Scale bar $=500 \mu \mathrm{m}(\mathbf{C})$.

oltipraz diet group, confirming its antioxidant effect (Figure 5B). The oltipraz diet yielded a significantly lower number of focus scores (Figure 5C), which was accompanied by a significant decrease in the expression of inflammatory cytokine IL- $1 \beta$ and TNF- $\alpha$ mRNA levels in the regular diet. There was no change in the levels of MHC II, $I F N-\gamma$, and cathepsin $S$. There was a significant increase in the transcripts of GST-P1, a gene up-regulated by oltipraz, in lacrimal glands in the oltipraz diet group (Figure 5D). A decrease in the $\mathrm{CD} 45^{+} \mathrm{CD} 4^{+} \mathrm{T}$ cells infiltrating the lacrimal glands was observed by flow cytometry in the oltipraz group (Figure 5E). Infiltration of B cells was investigated at the gene level using $C D 19$ specific probes, and there was a significant decrease in $C D 19$ mRNA in mice subjected to the oltipraz diet (Figure 5D). Furthermore, evaluation of conjunctival goblet cells showed that treatment with the antioxidant diet significantly improved age-related goblet cell loss (Figure 5F).

These results indicate that oltipraz diet improved agerelated dry eye by decreasing oxidative stress markers, 
decreasing lymphocytic infiltration and inflammatory markers, and improving goblet cell density.

\section{Discussion}

With increased life expectancy, age-related diseases are also expected to increase. There is a great effort to find new therapies to improve the quality of life and prevent diseases frequently seen in the aged population. Oxidative stress has been recognized as part of the aging process. Many of the questions in this study address gaps in knowledge related to aging, with a focus on the lacrimal gland and ocular surface. This study showed that aging is associated with increased inflammatory and oxidative stress markers. A diet with an Nrf2 inducer improved age-related dry eye, whereas $\mathrm{Nrf}^{-/-}$mice had worse lacrimal gland infiltration with aging.

Aged lacrimal glands had considerable lymphocytic infiltration, resembling the infiltration seen in other animal models of Sjögren syndrome. ${ }^{46}$ The infiltration in some glands was organized in concentric areas, resembling germinative centers (Figure 1). Similar to our findings, histologic evaluation of human cadaveric lacrimal glands showed ductal dilatation that was more prevalent in older cadavers. ${ }^{47}$ Studies in lacrimal gland biopsies have also identified considerable immune infiltration and loss of acinar parenchyma in older cadavers and aged rodents. ${ }^{47,48}$ Draper et $\mathrm{al}^{49}$ have shown a significant decrease in total protein content and peroxidase secretion at basal and agonist stimulation. A paradoxical increase in tear volume in aged C57BL/6 mice when collected at the tear meniscus has been shown by our group and others. ${ }^{50,51}$ The levels of certain immunoglobulins in tears are also altered in aged mice. ${ }^{52}$

The evaluation of tear cytokines showed a progressive increase in IFN- $\gamma$ and IL-12p70, accompanied by a sharp decrease in VEGF levels as early as 12 months of age. IFN$\gamma$ and IL-13 have opposite effects on the ocular surface, promoting goblet cell apoptosis and homeostatic maintenance, respectively. ${ }^{28,32}$ Healthy subjects have increased ocular symptoms and worse tear breakup film as they age. ${ }^{41,42}$ It has been shown that IL-8, IL-6, TNF- $\alpha$ concentration levels had a positive correlation (increase) with age in aged subjects who did not have dry eye. ${ }^{42}$ At the same time, aged tears have decreased levels of specific growth factors, such as insulin-like growth factor type $1 .^{53}$ The net result is proinflammatory tears. VEGF has potent angiogenesis properties; however, it can also be neuroprotective in vitro and in vivo. ${ }^{54,55}$ VEGF expression can be found in cornea epithelial cells, ciliary body and retina, and lacrimal gland. ${ }^{5-58}$ VEGF is secreted in tears of normal subjects, ${ }^{59}$ and increased levels are found in tears of diabetic patients who progressed to diabetic retinopathy. ${ }^{60}$ The sharp decrease in VEGF in tears of aged mice corresponded to the same time points when decreased corneal innervation and corneal sensitivity are observed, ${ }^{61,62}$ suggesting loss of
VEGF in tears might facilitate corneal neuron loss, although the precise mechanisms need further investigation.

A significant increase in the levels of MHC II, IFN- $\gamma$, IL- $1 \beta$, TNF- $\alpha$, and cathepsin S, both at mRNA and protein levels, and increased phosphorylation of p65 in the NF- $\kappa \mathrm{B}$ pathway were observed in the aged lacrimal gland. Bian et $\mathrm{al}^{37}$ showed an increase in $M H C I I, I L-1 \beta, I L-12$, and $I F N-\gamma$ mRNA transcripts protein expression in the conjunctiva of 24-month-old female C57BL/6 mice. A typical feature of aging is a chronic, low-grade inflammatory status referred to as inflammaging, characterized by a general increase in the production of proinflammatory cytokines, such as IL-6, TNF- $\alpha$, and IL-1 $\beta$. Increased serum inflammatory mediators are associated with age-related diseases. ${ }^{63-65}$ Increased serum levels of transforming growth factor- $\beta$ in centenarians can be considered a biomarker of good health, ${ }^{66}$ whereas increased serum levels of IL-6 and TNF- $\alpha$ are predictors of disability and mortality in octogenarians and centenarians. ${ }^{67}$ Individual differences in regulating proinflammatory and anti-inflammatory cytokines may be critical in the outcome of age-related inflammatory immune response. Cathepsin $\mathrm{S}$ is a lysosomal protein that is highly abundant in the lysosomal compartments of phagocytic cells, such as antigen-presenting cells and macrophages, where it is thought to participate in the MHC II presentation. ${ }^{68}$ Interestingly, cathepsin $\mathrm{S}$ is also found in lacrimal gland acinar cells, ${ }^{69,70}$ and increased levels of cathepsin $\mathrm{S}$ in tears have been suggested as a novel biomarker in dry eye and Sjögren syndrome. ${ }^{71} \mathrm{NF}-$ $\kappa \mathrm{B}$ is a major inflammation-signaling pathway used by epithelial cells and dendritic cells. Knockout of the negative regulator nfkb1 subunit of the transcription factor NF$\kappa \mathrm{B}$ has been shown to induce premature aging in mice, because of constitutive activation of the NF- $\mathrm{KB}$ pathway, ${ }^{72}$ and modulation of NF- $\kappa \mathrm{B}$ pathway has been proposed as an anti-aging therapy. ${ }^{73}$

Many theories of aging aim to understand the causes of cell decline and dysfunction that accompany chronological aging. The concept of oxidative stress leading to aging was first proposed in 1956 by Harman. ${ }^{74}$ Nitrotyrosine has been identified as an indicator of cellular damage, inflammation, and production of nitric oxide 3 , whereas 4-HNE, one of the main products of lipid peroxidation, is increased in oxidative stress. The results showed increased levels of both markers, confirming increased oxidative stress levels in the aged lacrimal gland. Previous studies have demonstrated a link between increased oxidative stress levels and ocular surface disease and lacrimal gland inflammation. ${ }^{75}$ Increased lacrimal gland infiltration, inflammation, and decreased tear secretion in inducible Tet-mev-1 mice has been shown to occur. Due to increased levels of ROS secondary to a higher electron transport chain in mitochondria. ${ }^{75}$ The superoxide dismutase ${ }^{-1-}$ mice have accelerated aging, mitochondrial dysfunction, and lacrimal gland infiltration. Increased lipid and protein oxidation markers have been found in the conjunctiva of patients with dry eye and 
A

Standard diet Standard or oltipraz diet

Birth End of the study

B
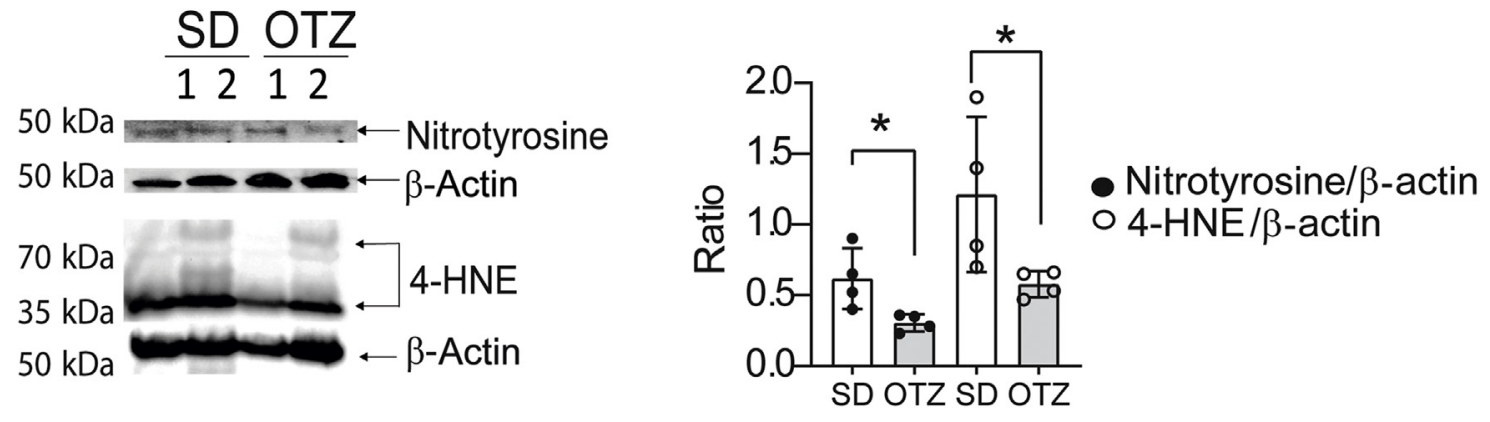

C H\&E
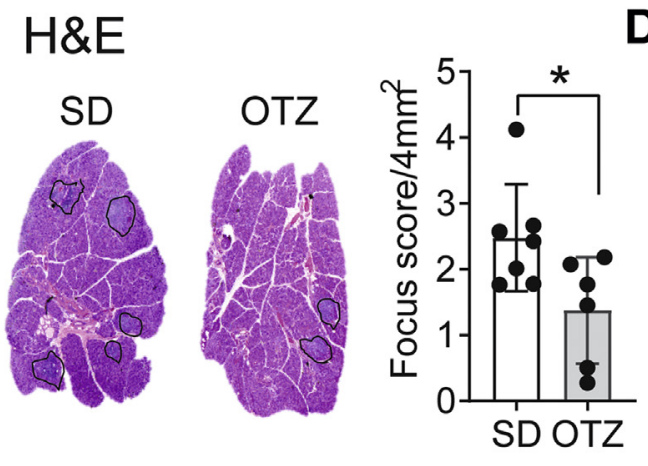

D

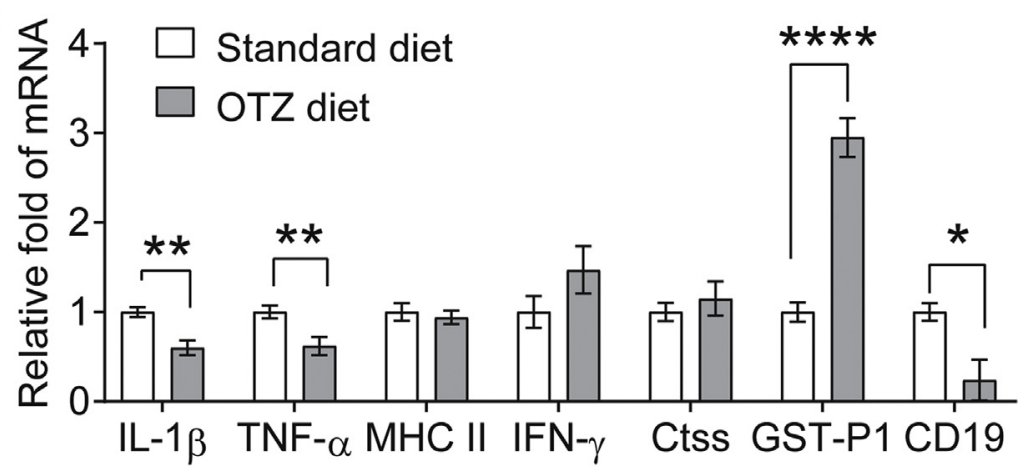

E
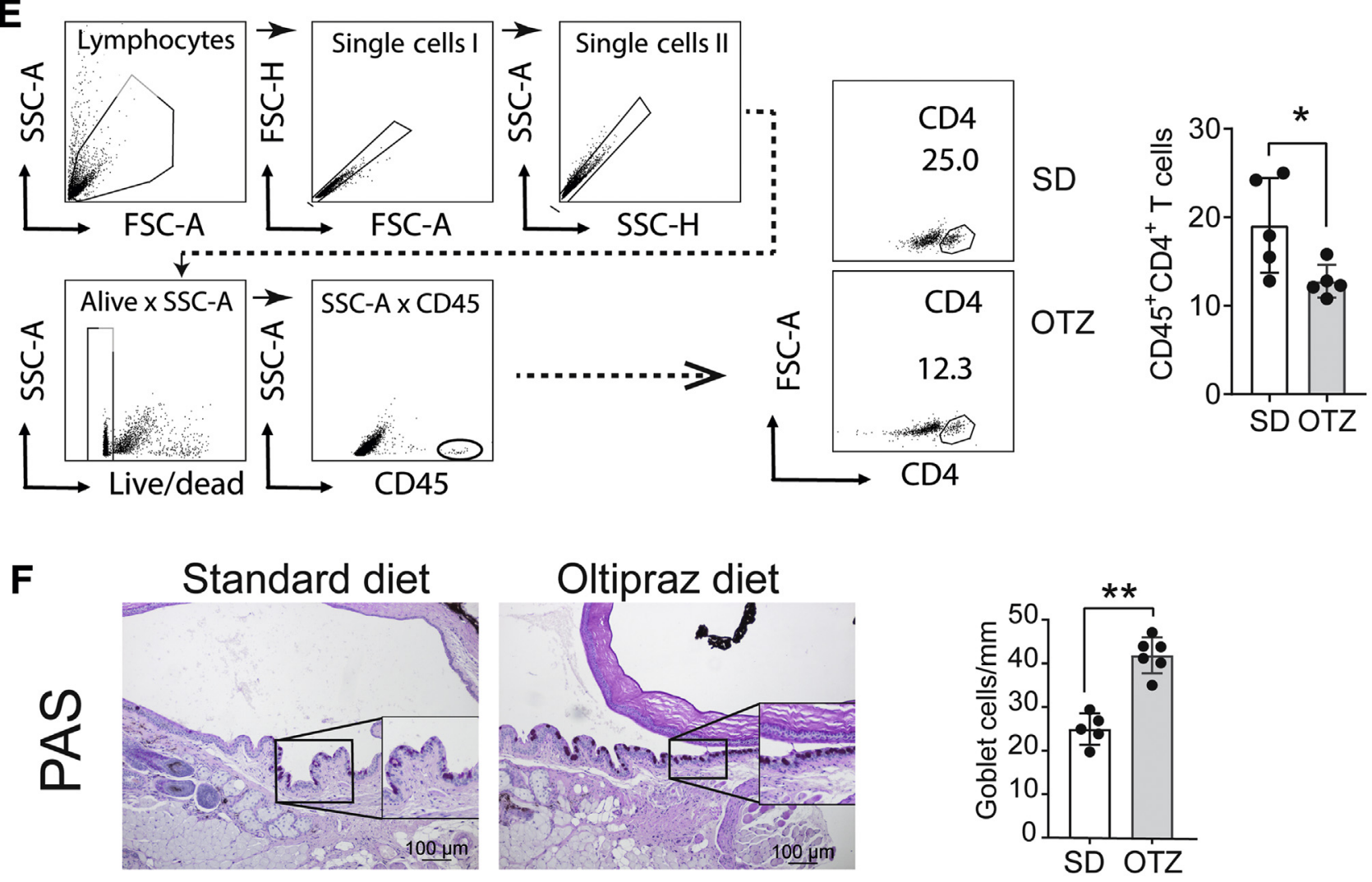
Sjögren syndrome. ${ }^{5,43,44,76,77}$ There is an increased interest in modulating oxidative stress damage as a therapy for dry eye. ${ }^{11-17}$

There is increasing evidence in the literature regarding the role of $\mathrm{Nrf} 2$ and aging. $\mathrm{Nrf} 2^{-/-}$mice have been shown to develop accelerated aging in the retina and have increased inflammatory responses to lipopolysaccharide. $^{78,79}$ The Hutchinson-Gilford progeria syndrome, which has accelerated aging, has been shown to have impaired Nrf2 transcriptional activity and consequently increased chronic oxidative stress. ${ }^{80}$ The findings showing that aging is accompanied by oxidative stress were provided by evaluating the $\mathrm{Nrf}^{-/-}$mice, in which lacrimal gland focus score, corneal barrier disruption, and inflammatory markers were increased as early as 2 to 3 months of age (Figure 4). Chronological aging to 1 year increased both the foci and the inflammation to levels higher than the ones observed in the 24-month-old C57BL/6 mice. Furthermore, $\mathrm{Nrf}^{-1-}$ mice exhibited high levels of proinflammatory cytokines. $^{81}$

There was a significant goblet cell loss with aging in this study in the C57BL/6 mice, but no difference in the $\mathrm{Nrf}^{-1-}$ strain as compared with wild-type mice. Goblet cells are highly secretory cells that secrete immunoregulatory factors, such as retinoic acid and transforming growth factor- $\beta$, in addition to mucins. ${ }^{82-84}$ Maintenance of conjunctival goblet cells has been associated with ocular health; several US Food and Drug Administration-approved drugs for dry eye improve goblet cell density. ${ }^{85-89}$ Goblet cells are responsive to the inflammatory milieu in the conjunctiva. It has been shown that IL-13 is a homeostatic factor for goblet cells, whereas IFN- $\gamma$ causes apoptosis, conjunctival metaplasia, and induction of unfolded protein response in goblet

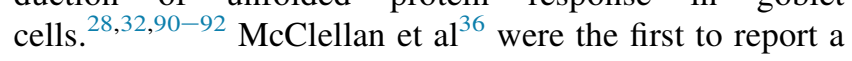
significant decrease in conjunctival goblet cells in aged C57BL/6 mice. The 15-month-old IFN- $\gamma$ knockout C57BL/6 mice have decreased age-related goblet cell loss compared with age- and sex-matched controls. ${ }^{26}$ Interestingly, Lpr mice in a Balb/c background develop several Sjögren syndrome features, but have increased conjunctival goblet cell density compared with wild-type mice. ${ }^{93}$ This is thought to be related to the mouse background, as Balb/c mice are type 2 helper T-cell-prone mice.
Some studies have shown that aging can be delayed. Studies with calorie restriction without malnutrition have shown that lifespan can be expanded in worms, rats, and mice. ${ }^{94,95}$ The administration of antioxidant-rich diets can be used to delay free radical activity in age-associated physiological changes and increase body lifespan. ${ }^{19,74,96,97}$ Our studies showed that the use of an Nrf2-inducing diet (oltipraz) for 8 weeks in 19month-old mice showed not only an improvement in oxidative stress levels and lacrimal gland focus score, but also a reduction in $I L-1 \beta$ and $T N F-\alpha$, but not $M H C$ II, cathepsin $S$, and IFN- $\gamma$. There was also a beneficial effect on the ocular surface, as an increase in conjunctival goblet cells was noted. Published studies from our laboratory have shown that C57BL/6 mice display loss of goblet cells around middle age. ${ }^{36}$ Treatment was initiated at 15.5 to 17 months to demonstrate therapeutic rather than preventative effects. However, it is possible that an earlier start (before 15 months) or prolonged treatment ( $>8$ weeks) could further modulate the age-related increase in MHC II, IFN- $\gamma$, and cathepsin S. Oltipraz was initially used to inhibit tumor growth in different organs in rodents and recently has been used for therapy and prevention of oxidative stress, both in vitro and in vivo. ${ }^{19,98-100}$ Oltipraz diet for 2 weeks in 18-month-old mice increased glutathione levels in the liver. ${ }^{19}$ In cisplatininduced kidney disease, oltipraz improved cell survival and increased antioxidant genes $G C L C$ and $N Q O 1$ in vitro. ${ }^{99}$ Oltipraz oral gavage also improved heart function and decreased IL-1 $\beta$ and TNF- $\alpha$ protein levels in a heart failure model in rats. ${ }^{100}$ Systemic activation of Nrf2 by Keapl knockdown has been shown to modulate autoimmunity in the scurfy mouse, an autoimmune strain devoid of regulatory $\mathrm{T}$ cells; striking ameliorated results were seen in the liver, skin, and lung pathology. ${ }^{101}$ Of note, the authors showed a significant decrease in cytokine production by $\mathrm{CD} 4$ and $\mathrm{CD} 8^{+} \mathrm{T}$ cells and a significantly increased life span survival of these autoimmune mice (60 versus 21 days). ${ }^{101}$

Although the scientific community is making progress in better understanding the confluence between aging and ocular diseases, there is a lack of information on how these mechanisms can be associated. The current studies show that targeting oxidative stress with Nrf2-inducing therapies can delay and modify age-related alterations in both the lacrimal gland and ocular surface. They also shed light on the intersection of inflammation, aging, and ocular surface

\footnotetext{
Figure 5 Nuclear factor erythroid derived-2-related factor 2-inducing diet improves age-related dry eye. A: Schematic of diets used. C57BL/6 mice aged 15.5 to 17 months were randomized to receive either standard diet (SD) or a medicated diet containing $0.1 \%$ oltipraz (OTZ) for 2 months. B: Western blot (WB) analysis for nitrotyrosine, 4-hydroxynonenal (4-HNE), and $\beta$-actin in lacrimal gland (LG) lysates comparing SD and OTZ diets and densitometry showing WB ratios after 2 months; U-test was used. C: Representative LG sections stained with hematoxylin and eosin (H\&E), showing decreased focus score after the 0TZ diet; accumulative data on the graph on the right. Areas of infiltration are demarcated; U-test was used. D: Gene expression analysis of inflammatory cytokines and glutathione S-transferase P (GST-P1), showing decreased inflammatory mRNA in LG after OTZ diet. E: Representative dot plots, showing gating strategy of collagenase-digested lacrimal glands stained with live/dead dye, CD45, and CD4 antibodies. Accumulative graph on the right shows the frequency of $\mathrm{CD}_{4} 5^{+} \mathrm{CD4}^{+} \mathrm{T}$ cells measured by flow cytometry. $U$-test was used. F: Representative images of conjunctiva sections stained with periodic acid-Schiff (PAS), showing increased goblet cell density with the OTZ diet. Insets: Higher magnifications of the boxed areas-accumulative graph on the right; $U$-test was used. $n=4$ per group (B); $n=6$ to 7 per group (C); $n=4$ to 5 per group (D); $n=5$ per group (E); $n=6$ per group (F). ${ }^{*} P<0.05, * * P<0.01$, and $* * * * P<0.0001$. Scale bar $=100 \mu \mathrm{m}(\mathbf{F})$. Ctss, cathepsin S; FSC-A, forward scatter area; FSC-H, forward scatter height; IFN- $\gamma$, interferon- $\gamma ;$ MHC, major histocompatibility complex; SSC-A, side scatter area; SSC-H, side scatter height; TNF- $\alpha$, tumor necrosis factor- $\alpha$.
} 
health. New treatments and therapeutic approaches in this direction have the potential to reduce ocular diseases that are accompanied by aging.

\section{Acknowledgments}

We thank Leiqi Zhang for expert management of the aged C57BL/6 colony; and Sarah Amra for the histology preparation.

\section{References}

1. Yin Y, Zong R, Bao X, Zheng X, Cui H, Liu Z, Zhou Y: Oxidative stress suppresses cellular autophagy in corneal epithelium. Invest Ophthalmol Vis Sci 2018, 59:3286-3293

2. Sies H, Berndt C, Jones DP: Oxidative stress. Annu Rev Biochem 2017, 86:715-748

3. Pinazo-Duran MD, Gallego-Pinazo R, Garcia-Medina JJ, ZanonMoreno V, Nucci C, Dolz-Marco R, Martinez-Castillo S, GalbisEstrada C, Marco-Ramirez C, Lopez-Galvez MI, Galarreta DJ, Diaz-Llopis M: Oxidative stress and its downstream signaling in aging eyes. Clin Interv Aging 2014, 9:637-652

4. Yarosz EL, Chang $\mathrm{CH}$ : The role of reactive oxygen species in regulating $\mathrm{T}$ cell-mediated immunity and disease. Immune Netw 2018, 18:e14

5. Choi W, Lian C, Ying L, Kim GE, You IC, Park SH, Yoon KC: Expression of lipid peroxidation markers in the tear film and ocular surface of patients with non-Sjogren syndrome: potential biomarkers for dry eye disease. Curr Eye Res 2016, 41:1143-1149

6. Sacca SC, Cutolo CA, Ferrari D, Corazza P, Traverso CE: The eye, oxidative damage and polyunsaturated fatty acids. Nutrients 2018, 10

7. Uchino Y, Kawakita T, Ishii T, Ishii N, Tsubota K: A new mouse model of dry eye disease: oxidative stress affects functional decline in the lacrimal gland. Cornea 2012, 31 Suppl 1:S63-S67

8. Kojima T, Dogru M, Higuchi A, Nagata T, Ibrahim OM, Inaba T, Tsubota K: The effect of Nrf2 knockout on ocular surface protection from acute tobacco smoke exposure: evidence from Nrf2 knockout mice. Am J Pathol 2015, 185:776-785

9. Kemmerer ZA, Ader NR, Mulroy SS, Eggler AL: Comparison of human Nrf2 antibodies: a tale of two proteins. Toxicol Lett 2015, 238:83-89

10. Chen J, Wang L, Chen Y, Sternberg P, Cai J: Phosphatidylinositol 3 kinase pathway and 4-hydroxy-2-nonenal-induced oxidative injury in the RPE. Invest Ophthalmol Vis Sci 2009, 50:936-942

11. Li YJ, Luo LJ, Harroun SG, Wei SC, Unnikrishnan B, Chang HT, Huang YF, Lai JY, Huang CC: Synergistically dual-functional nano eye-drops for simultaneous anti-inflammatory and anti-oxidative treatment of dry eye disease. Nanoscale 2019, 11:5580-5594

12. Park B, Jo K, Lee TG, Hyun S-W, Kim JS, Kim C-S: Polydatin inhibits NLRP3 inflammasome in dry eye disease by attenuating oxidative stress and inhibiting the NF- $K$ B pathway. Nutrients 2019, 11:E2792

13. Dogru M, Kojima T, Simsek C, Tsubota K: Potential role of oxidative stress in ocular surface inflammation and dry eye disease. Invest Ophthalmol Vis Sci 2018, 59:DES163-DES168

14. Choi W, Lee JB, Cui L, Li Y, Li Z, Choi JS, Lee HS, Yoon KC: Therapeutic efficacy of topically applied antioxidant medicinal plant extracts in a mouse model of experimental dry eye. Oxid Med Cell Longev 2016, 2016:4727415

15. Li J, Ruzhi D, Hua X, Zhang L, Lu F, Coursey TG, Pflugfelder SC, Li DQ: Blueberry component pterostilbene protects corneal epithelial cells from inflammation via anti-oxidative pathway. Sci Rep 2016, 6: 19408

16. Deng R, Hua X, Li J, Chi W, Zhang Z, Lu F, Zhang L, Pflugfelder SC, Li DQ: Oxidative stress markers induced by hyperosmolarity in primary human corneal epithelial cells. PLoS One 2015, 10:e0126561

17. Hua X, Deng R, Li J, Chi W, Su Z, Lin J, Pflugfelder SC, Li DQ: Protective effects of $\mathrm{L}$-carnitine against oxidative injury by hyperosmolarity in human corneal epithelial cells. Invest Ophthalmol Vis Sci 2015, 56:5503-5511

18. Merrell MD, Jackson JP, Augustine LM, Fisher CD, Slitt AL, Maher JM, Huang W, Moore DD, Zhang Y, Klaassen CD, Cherrington NJ: The Nrf2 activator oltipraz also activates the constitutive androstane receptor. Drug Metab Dispos 2008, 36: $1716-1721$

19. Stohs SJ, Lawson TA, Anderson L, Bueding E: Effects of oltipraz, BHA, ADT and cabbage on glutathione metabolism, DNA damage and lipid peroxidation in old mice. Mech Ageing Dev 1986, 37:137-145

20. Committee for the Update of the Guide for the Care and Use of Laboratory Animals: National Research Council: Guide for the Care and Use of Laboratory Animals: Eighth Edition. Washington, DC, National Academies Press, 2011

21. Chan K, Lu R, Chang JC, Kan YW: NRF2, a member of the NFE2 family of transcription factors, is not essential for murine erythropoiesis, growth, and development. Proc Natl Acad Sci U S A 1996, 93:13943-13948

22. Dutta S, Sengupta P: Men and mice: relating their ages. Life Sci 2016, 152:244-248

23. Flurkey KCJ, Harrison DE: The mouse in aging research. Edited by Fox JG, Davisson M, Newcomer C, Quimby F, Smith A. In The Mouse in Biomedical Research. ed 2. Burlington, MA: American College Laboratory Animal Medicine (Elsevier), 2007. pp. 637-672

24. Moss SE, Klein R, Klein BE: Prevalence of and risk factors for dry eye syndrome. Arch Ophthalmol 2000, 118:1264-1268

25. Schaumberg DA, Sullivan DA, Buring JE, Dana MR: Prevalence of dry eye syndrome among US women. Am J Ophthalmol 2003, 136: 318-326

26. Volpe EA, Henriksson JT, Wang C, Barbosa FL, Zaheer M, Zhang X, Pflugfelder SC, de Paiva CS: Interferon-gamma deficiency protects against aging-related goblet cell loss. Oncotarget 2016, 7: 64605-66461

27. Coursey TG, Bohat R, Barbosa FL, Pflugfelder SC, de Paiva CS: Desiccating stress-induced chemokine expression in the epithelium is dependent on upregulation of NKG2D/RAE-1 and release of IFN-gamma in experimental dry eye. J Immunol 2014, 193: $5264-5272$

28. de Paiva CS, Villarreal AL, Corrales RM, Rahman HT, Chang VY, Farley WJ, Stern ME, Niederkorn JY, Li DQ, Pflugfelder SC: Dry eye-induced conjunctival epithelial squamous metaplasia is modulated by interferon-\{gamma\}. Invest Ophthalmol Vis Sci 2007, $48: 2553-2560$

29. de Paiva CS, Corrales RM, Villarreal AL, Farley W, Li DQ, Stern ME, Pflugfelder SC: Apical corneal barrier disruption in experimental murine dry eye is abrogated by methylprednisolone and doxycycline. Invest Ophthalmol Vis Sci 2006, 47: $2847-2856$

30. Zhang X, Schaumburg CS, Coursey TG, Siemasko KF, Volpe EA, Gandhi NB, Li DQ, Niederkorn JY, Stern ME, Pflugfelder SC, de Paiva CS: CD8(+) cells regulate the $\mathrm{T}$ helper-17 response in an experimental murine model of Sjogren syndrome. Mucosal Immunol 2014, 7:417-427

31. de Paiva CS, Volpe EA, Gandhi NB, Zhang X, Zheng X, Pitcher JD III, Farley WJ, Stern ME, Niederkorn JY, Li DQ, Flavell RA, Pflugfelder SC: Disruption of TGF-beta signaling improves ocular surface epithelial disease in experimental autoimmune keratoconjunctivitis sicca. PLoS One 2011, 6:e29017

32. de Paiva CS, Raince JK, McClellan AJ, Shanmugam KP, Pangelinan SB, Volpe EA, Corrales RM, Farley WJ, Corry DB, Li DQ, Pflugfelder SC: Homeostatic control of conjunctival mucosal goblet cells by NKT-derived IL-13. Mucosal Immunol 2011, 4:397-408 
33. Barbosa FL, Xiao Y, Bian F, Coursey TG, Ko BY, Clevers H, de Paiva CS, Pflugfelder SC: Goblet cells contribute to ocular surface immune tolerance-implications for dry eye disease. Int J Mol Sci 2017, 18:1-13

34. Bian F, Barbosa FL, Corrales RM, Pelegrino FS, Volpe EA, Pflugfelder SC, de Paiva CS: Altered balance of interleukin13/interferon-gamma contributes to lacrimal gland destruction and secretory dysfunction in CD25 knockout model of Sjogren's syndrome. Arthritis Res Ther 2015, 17:53

35. Franceschi C, BonaFe M: Centenarians as a model for healthy aging. Biochem Soc Trans 2003, 31:457-461

36. McClellan AJ, Volpe EA, Zhang X, Darlington GJ, Li DQ, Pflugfelder SC, de Paiva CS: Ocular surface disease and dacryoadenitis in aging C57BL/6 mice. Am J Pathol 2014, 184:631-643

37. Bian F, Xiao Y, Barbosa FL, de Souza RG, Hernandez H, Yu Z, Pflugfelder SC, de Paiva CS: Age-associated antigen-presenting cell alterations promote dry-eye inducing Th1 cells. Mucosal Immunol 2019, 12:897-908

38. Nasu M, Matsubara O, Yamamoto H: Post-mortem prevalence of lymphocytic infiltration of the lacrymal gland: a comparative study in autoimmune and non-autoimmune diseases. J Pathol 1984, 143:11-15

39. Alves M, Calegari VC, Cunha DA, Saad MJ, Velloso LA, Rocha EM: Increased expression of advanced glycation end-products and their receptor, and activation of nuclear factor kappa-B in lacrimal glands of diabetic rats. Diabetologia 2005, 48:2675-2681

40. Lam H, Blieden L, de Paiva CS, Farley WJ, Stern ME, Pflugfelder SC: Tear cytokine profiles in dysfunctional tear syndrome. Am J Ophthalmol 2009, 147:198-205

41. Di Zazzo A, Micera A, Coassin M, Varacalli G, Foulsham W, De Piano M, Bonini S: Inflamm aging at ocular surface: clinical and biomolecular analyses in healthy volunteers. Invest Ophthalmol Vis Sci 2019, 60:1769-1775

42. Micera A, Di Zazzo A, Esposito G, Longo R, Foulsham W, Sacco R, Sgrulletta R, Bonini S: Age-related changes to human tear composition. Invest Ophthalmol Vis Sci 2018, 59:2024-2031

43. Wakamatsu TH, Dogru M, Matsumoto Y, Kojima T, Kaido M, Ibrahim OM, Sato EA, Igarashi A, Ichihashi Y, Satake Y, Shimazaki J, Tsubota K: Evaluation of lipid oxidative stress status in Sjogren syndrome patients. Invest Ophthalmol Vis Sci 2013, 54: 201-210

44. Cejkova J, Ardan T, Simonova Z, Cejka C, Malec J, Dotrelova D, Brunova B: Decreased expression of antioxidant enzymes in the conjunctival epithelium of dry eye (Sjogren's syndrome) and its possible contribution to the development of ocular surface oxidative injuries. Histol Histopathol 2008, 23:1477-1483

45. Kojima T, Wakamatsu TH, Dogru M, Ogawa $\mathrm{Y}$, Igarashi A, Ibrahim OM, Inaba T, Shimizu T, Noda S, Obata H, Nakamura S, Wakamatsu A, Shirasawa T, Shimazaki J, Negishi K, Tsubota K: Age-related dysfunction of the lacrimal gland and oxidative stress: evidence from the $\mathrm{Cu}, \mathrm{Zn}$-superoxide dismutase-1 (Sod1) knockout mice. Am J Pathol 2012, 180:1879-1896

46. Coursey TG, Bian F, Zaheer M, Pflugfelder SC, Volpe EA, de Paiva CS: Age-related spontaneous lacrimal keratoconjunctivitis is accompanied by dysfunctional $\mathrm{T}$ regulatory cells. Mucosal Immunol 2017, 10:743-756

47. Damato BE, Allan D, Murray SB, Lee WR: Senile atrophy of the human lacrimal gland: the contribution of chronic inflammatory disease. Br J Ophthalmol 1984, 68:674-680

48. Draper CE, Adeghate E, Lawrence PA, Pallot DJ, Garner A, Singh J: Age-related changes in morphology and secretory responses of male rat lacrimal gland. J Auton Nerv Syst 1998, 69:173-183

49. Draper CE, Adeghate EA, Singh J, Pallot DJ: Evidence to suggest morphological and physiological alterations of lacrimal gland acini with ageing. Exp Eye Res 1999, 68:265-276

50. De Silva MEH, Hill LJ, Downie LE, Chinnery HR: The effects of aging on corneal and ocular surface homeostasis in mice. Invest Ophthalmol Vis Sci 2019, 60:2705-2715
51. Shikama Y, Kurosawa M, Furukawa M, Ishimaru N, Matsushita K: Involvement of adiponectin in age-related increases in tear production in mice. Aging (Albany NY) 2019, 11:8329-8346

52. de Souza RG, de Paiva CS, Alves MR: Age-related autoimmune changes in lacrimal glands. Immune Netw 2019, 19:e3

53. Patel R, Zhu M, Robertson DM: Shifting the IGF-axis: an age-related decline in human tear IGF-1 correlates with clinical signs of dry eye. Growth Horm IGF Res 2018, 40:69-73

54. Góra-Kupilas K, Jośko J: The neuroprotective function of vascular endothelial growth factor (VEGF). Folia Neuropathol 2005, 43: 31-39

55. Nishijima K, Ng YS, Zhong L, Bradley J, Schubert W, Jo N, Akita J, Samuelsson SJ, Robinson GS, Adamis AP, Shima DT: Vascular endothelial growth factor-A is a survival factor for retinal neurons and a critical neuroprotectant during the adaptive response to ischemic injury. Am J Pathol 2007, 171:53-67

56. Colafrancesco V, Cirulli F, Rossi S, Berry A, Aloe L: Anti-NGFantibody administration as collyrium reduces the presence of NGF and enhances the expression of VEGF in the retina, lacrimal gland and hippocampus. Neurosci Lett 2009, 463:203-206

57. van Setten GB: Vascular endothelial growth factor (VEGF) in normal human corneal epithelium: detection and physiological importance. Acta Ophthalmol Scand 1997, 75:649-652

58. Ford KM, Saint-Geniez M, Walshe TE, D'Amore PA: Expression and role of VEGF-a in the ciliary body. Invest Ophthalmol Vis Sci 2012, 53:7520-7527

59. Vesaluoma M, Teppo AM, Grönhagen-Riska C, Tervo T: Release of TGF-beta 1 and VEGF in tears following photorefractive keratectomy. Curr Eye Res 1997, 16:19-25

60. Ang WJ, Zunaina E, Norfadzillah AJ, Raja-Norliza RO, Julieana M, Ab-Hamid SA, Mahaneem M: Evaluation of vascular endothelial growth factor levels in tears and serum among diabetic patients. PLoS One 2019, 14:e221481

61. Stepp MA, Pal-Ghosh S, Tadvalkar G, de Paiva CS: Parity attenuates intraepithelial corneal sensory nerve loss in female mice. Int J Mol Sci 2020, 21:5172

62. Stepp MA, Pal-Ghosh S, Tadvalkar G, Williams A, Pflugfelder SC, de Paiva CS: Reduced intraepithelial corneal nerve density and sensitivity accompany desiccating stress and aging in C57BL/6 mice. Exp Eye Res 2018, 169:91-98

63. Gerli R, Monti D, Bistoni O, Mazzone AM, Peri G, Cossarizza A, Di GM, Cesarotti ME, Doni A, Mantovani A, Franceschi C, Paganelli R: Chemokines, sTNF-Rs and sCD30 serum levels in healthy aged people and centenarians. Mech Ageing Dev 2000, 121:37-46

64. Franceschi C, BonaFe M, Valensin S, Olivieri F, De LM, Ottaviani E, De BG: Inflamm-aging: an evolutionary perspective on immunosenescence. Ann N Y Acad Sci 2000, 908:244-254

65. Bruunsgaard $\mathrm{H}$, Pedersen $\mathrm{M}$, Pedersen BK: Aging and proinflammatory cytokines. Curr Opin Hematol 2001, 8:131-136

66. Carrieri G, Marzi E, Olivieri F, Marchegiani F, Cavallone L, Cardelli M, Giovagnetti S, Stecconi R, Molendini C, Trapassi C, De BG, Kletsas D, Franceschi C: The G/C915 polymorphism of transforming growth factor beta1 is associated with human longevity: a study in Italian centenarians. Aging Cell 2004, 3:443-448

67. Bruunsgaard $\mathrm{H}$, Andersen-Ranberg $\mathrm{K}$, Hjelmborg J, Pedersen BK, Jeune B: Elevated levels of tumor necrosis factor alpha and mortality in centenarians. Am J Med 2003, 115: $278-283$

68. Shi GP, Villadangos JA, Dranoff G, Small C, Gu L, Haley KJ, Riese R, Ploegh HL, Chapman HA: Cathepsin S required for normal MHC class II peptide loading and germinal center development. Immunity 1999, 10:197-206

69. Li X, Wu K, Edman M, Schenke-Layland K, MacVeigh-Aloni M, Janga SR, Schulz B, Hamm-Alvarez SF: Increased expression of cathepsins and obesity-induced proinflammatory cytokines in lacrimal glands of male NOD mouse. Invest Ophthalmol Vis Sci 2010, 51:5019-5029 
70. Wendt W, Lubbert H, Stichel CC: Upregulation of cathepsin S in the aging and pathological nervous system of mice. Brain Res 2008, 1232:7-20

71. Hamm-Alvarez SF, Janga SR, Edman MC, Madrigal S, Shah M, Frousiakis SE, Renduchintala K, Zhu J, Bricel S, Silka K, Bach D, Heur M, Christianakis S, Arkfeld DG, Irvine J, Mack WJ, Stohl W: Tear cathepsin S as a candidate biomarker for Sjogren's syndrome. Arthritis Rheumatol 2014, 66:1872-1881

72. Jurk D, Wilson C, Passos JF, Oakley F, Correia-Melo C, Greaves L, Saretzki G, Fox C, Lawless C, Anderson R, Hewitt G, Pender SL, Fullard N, Nelson G, Mann J, van de Sluis B, Mann DA, von Zglinicki T: Chronic inflammation induces telomere dysfunction and accelerates ageing in mice. Nat Commun 2014, 2:4172

73. Adler AS, Kawahara TL, Segal E, Chang HY: Reversal of aging by NFkappaB blockade. Cell Cycle 2008, 7:556-559

74. Harman D: Aging: a theory based on free radical and radiation chemistry. J Gerontol 1956, 11:298-300

75. Uchino Y, Kawakita T, Miyazawa M, Ishii T, Onouchi H, Yasuda K, Ogawa Y, Shimmura S, Ishii N, Tsubota K: Oxidative stress induced inflammation initiates functional decline of tear production. PLoS One 2012, 7:e45805

76. Li B, Sheng M, Li J, Yan G, Lin A, Li M, Wang W, Chen Y: Tear proteomic analysis of Sjogren syndrome patients with dry eye syndrome by two-dimensional-nano-liquid chromatography coupled with tandem mass spectrometry. Sci Rep 2014, 4:5772

77. Macri A, Scanarotti C, Bassi AM, Giuffrida S, Sangalli G, Traverso CE, Iester M: Evaluation of oxidative stress levels in the conjunctival epithelium of patients with or without dry eye, and dry eye patients treated with preservative-free hyaluronic acid $0.15 \%$ and vitamin B12 eye drops. Graefes Arch Clin Exp Ophthalmol 2015, 253:425-430

78. Zhao Z, Chen Y, Wang J, Sternberg P, Freeman ML, Grossniklaus HE, Cai J: Age-related retinopathy in NRF2-deficient mice. PLoS One 2011, 6:e19456

79. Liu X, Zhang X, Ding Y, Zhou W, Tao L, Lu P, Wang Y, Hu R: Nuclear factor E2-related factor-2 negatively regulates NLRP3 inflammasome activity by inhibiting reactive oxygen species-induced NLRP3 priming. Antioxid Redox Signal 2017, 26:28-43

80. Kubben N, Zhang W, Wang L, Voss TC, Yang J, Qu J, Liu GH, Misteli T: Repression of the antioxidant NRF2 pathway in premature aging. Cell 2016, 165:1361-1374

81. Ma TJ, Lan DH, He SZ, Ye Z, Li P, Zhai W, Chen WQ, Huang Y, Fu Y, Sun A, Wang YB, Ye Z, Li JL, Gao Y, Yan XL, Li ZH: Nrf2 protects human lens epithelial cells against $\mathrm{H} 2 \mathrm{O} 2$-induced oxidative and ER stress: the ATF4 may be involved. Exp Eye Res 2018, 169:28-37

82. Alam J, de Paiva CS, Pflugfelder SC: Immune - goblet cell interaction in the conjunctiva. Ocul Surf 2020, 18:326-334

83. Xiao Y, de Paiva CS, Yu Z, de Souza RG, Li DQ, Pflugfelder SC: Goblet cell-produced retinoic acid suppresses CD86 expression and IL-12 production in bone marrow-derived cells. Int Immunol 2018, $30: 457-470$

84. Contreras-Ruiz L, Masli S: Immunomodulatory cross-talk between conjunctival goblet cells and dendritic cells. PLoS One 2015, 10:e0120284

85. de Paiva CS, Pflugfelder SC, Ng SM, Akpek EK: Topical cyclosporine A therapy for dry eye syndrome. Cochrane Database Syst Rev 2019, 9:Cd010051
86. Alam J, de Souza RG, Yu Z, Stern ME, de Paiva CS, Pflugfelder SC: Calcineurin inhibitor voclosporin preserves corneal barrier and conjunctival goblet cells in experimental dry eye. J Ocul Pharmacol Ther 2020, 36:679-685

87. Zhang X, Volpe EA, Gandhi NB, Schaumburg CS, Siemasko KF, Pangelinan SB, Kelly SD, Hayday AC, Li DQ, Stern ME, Niederkorn JY, Pflugfelder SC, de Paiva CS: NK cells promote Th-17 mediated corneal barrier disruption in dry eye. PLoS One 2012, 7:e36822

88. Guimaraes de Souza R, Yu Z, Stern ME, Pflugfelder SC, de Paiva CS: Suppression of Th1-mediated keratoconjunctivitis sicca by lifitegrast. J Ocul Pharmacol Ther 2018, 34:543-549

89. Sall K, Stevenson OD, Mundorf TK, Reis BL; CsA Phase 3 Study Group: Two multicenter, randomized studies of the efficacy and safety of cyclosporine ophthalmic emulsion in moderate to severe dry eye disease. Ophthalmology 2000, 107:631-639

90. Tukler Henriksson J, Coursey TG, Corry DB, De Paiva CS, Pflugfelder SC: IL-13 stimulates proliferation and expression of mucin and immunomodulatory genes in cultured conjunctival goblet cells. Invest Ophthalmol Vis Sci 2015, 56:4186-4197

91. Coursey TG, Henriksson JT, Barbosa FL, de Paiva CS, Pflugfelder SC: Interferon-gamma-induced unfolded protein response in conjunctival goblet cells as a cause of mucin deficiency in Sjogren syndrome. Am J Pathol 2016, 186:1547-1558

92. Zhang X, Chen W, de Paiva CS, Corrales RM, Volpe EA, McClellan AJ, Farley WJ, Li DQ, Pflugfelder SC: Interferon-gamma exacerbates dry eye-induced apoptosis in conjunctiva through dual apoptotic pathways. Invest Ophthalmol Vis Sci 2011, 52:6279-6285

93. Diebold Y, Chen LL, Tepavcevic V, Ferdman D, Hodges RR, Dartt DA: Lymphocytic infiltration and goblet cell marker alteration in the conjunctiva of the MRL/MpJ-Fas(lpr) mouse model of Sjogren's syndrome. Exp Eye Res 2007, 84:500-512

94. Fontana L, Weiss EP, Villareal DT, Klein S, Holloszy JO: Long-term effects of calorie or protein restriction on serum IGF-1 and IGFBP-3 concentration in humans. Aging Cell 2008, 7:681-687

95. Fontana L, Villareal DT, Weiss EP, Racette SB, Steger-May K, Klein S, Holloszy JO: Calorie restriction or exercise: effects on coronary heart disease risk factors: a randomized, controlled trial. Am J Physiol Endocrinol Metab 2007, 293:E197-E202

96. Harman D: Nutritional implications of the free-radical theory of aging. J Am Coll Nutr 1982, 1:27-34

97. Kohn RR: Effect of antioxidants on life-span of C57BL mice. J Gerontol 1971, 26:378-380

98. Nelson KC, Armstrong JS, Moriarty S, Cai J, Wu M-WH, Sternberg JP, Jones DP: Protection of retinal pigment epithelial cells from oxidative damage by oltipraz, a cancer chemopreventive agent. Invest Ophthalmol Vis Sci 2002, 43:3550-3554

99. Atilano-Roque A, Wen X, Aleksunes LM, Joy MS: Nrf2 activators as potential modulators of injury in human kidney cells. Toxicol Rep 2016, 3:153-159

100. Tang Y, Guo M, Ma XY, Sun WP, Hao MH, Zhu HY: Oltipraz attenuates the progression of heart failure in rats through inhibiting oxidative stress and inflammatory response. Eur Rev Med Pharmacol Sci 2018, 22:8918-8923

101. Suzuki T, Murakami S, Biswal SS, Sakaguchi S, Harigae H, Yamamoto M, Motohashi H: Systemic activation of NRF2 alleviates lethal autoimmune inflammation in scurfy mice. Mol Cell Biol 2017, 37:e0063-17 